\title{
Mantle and Crustal Sources in the Genesis of Late-Hercynian Granitoids (NW Portugal): Geochemical and Sr-Nd Isotopic Constraints
}

\author{
G. Dias ${ }^{1 *}$, P.P. Simões ${ }^{1}$, N. Ferreira ${ }^{2}$ and J. Leterrier ${ }^{3}$ \\ ${ }^{1}$ Departamento de Ciências da Terra, Universidade do Minho, Campus de Gualtar, 4710-057 Braga, Portugal, \\ E-mail: graciete@dct.uminho.pt \\ 2 Instituto Geológico e Mineiro, Rua da Amieira, 4466-956 S. Mamede de Infesta, Portugal \\ ${ }^{3}$ Centre de Recherches Pétrographiques et Géochimiques, CNRS, B.P. 20, 54501 Vandoeuvre-lès-Nancy, France \\ * Corresponding author
}

(Manuscript received March 12, 2001; accepted August 21, 2001)

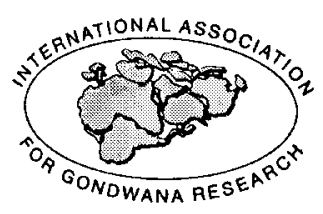

\begin{abstract}
Large volumes of granitoids were emplaced in the Hercynian Central Iberian Zone during the last ductile deformation phase (D3, 300-320 Ma). The biotite-rich granitoids are the most abundant: (1) syn-D3 granodiorites-monzogranites (313-319 Ma) with calc-alkaline and aluminopotassic affinities; (2) late-D3 granodiorites-monzogranites (306-311 $\mathrm{Ma}$ ), related to subalkaline and aluminopotassic series. These granitoids are associated with coeval gabbro-norite to granodiorite bodies and/or mafic microgranular enclaves. Both granitoids and basic-intermediate rocks show petrological, geochemical and isotopic evidence of interaction between felsic and mafic magmas.

The mantle-derived melts, represented by shoshonitic gabbro-norites, were probably derived from an enriched and isotopically homogeneous source ( $\mathrm{Sr}_{i}=0.7049$ to $0.7053, \varepsilon_{\mathrm{Nd}}=-2.1$ to -2.5 ). In some syn- and late-D3 plutons there are evidences of essentially crustal granites, represented by moderately peraluminous monzogranites of aluminopotassic affinity. They have similar $\mathrm{Nd}$ model ages $(1.4 \mathrm{Ga})$ but different isotopic compositions $\left(\mathrm{Sr}_{\mathrm{i}}=0.7089\right.$ to 0.7106 , $\varepsilon_{\mathrm{Nd}}=-5.6$ to -6.8 ), revealing a heterogeneous crust. Potential protoliths are metasedimentary (immature sediments) and/or felsic meta-igneous lower crust materials. Large amounts of hybrid magmas were generated by the interaction of these coeval mantle- and crust-derived liquids, giving rise to slightly peraluminous monzogranites/granodiorites of calc-alkaline and subalkaline affinities, which display more depleted isotopic compositions than the crustal end-members $\left(\mathrm{Sr}_{\mathrm{i}}=0.7064\right.$ to $0.7085, \varepsilon_{\mathrm{Nd}}=-4.4$ to -6.2$)$. Petrogenetic processes involving mingling and/or mixing and fractional crystallization (at variable degrees) in multiple reservoirs are suggested.

A major crustal growth event occurred in late-Hercynian times ( $-305-320 \mathrm{Ma})$ related to the input of juvenile mantle magmas and leading to the genesis of composite calc-alkaline and subalkaline plutons, largely represented in the Central Iberian Zone.
\end{abstract}

Key words: Iberian peninsula, Hercynian, hybrid granitoids, protoliths, geochemistry.

\section{Introduction}

The generation of granitic magmas is associated in space and time with growth of the continental crust, rather than just recycling (Patiño Douce, 1999). Hybridization processes involving coeval crustal and mantle components have been suggested to account for field, petrographic, chemical and isotopic features of granodiorites and monzogranites (Allègre and Ben Othman, 1980; Holden et al., 1987; Pankhurst et al., 1988; Didier and Barbarin, 1991 and references therein; Cocherie et al., 1994; Dias and Leterrier, 1994; Macera et al., 1994; Jayananda et al., 1995; Collins, 1996; D'Lemos, 1996; Galán et al., 1996; Janousek et al., 2000). The mafic microgranular enclaves and basic rocks, frequently associated with calcalkaline and subalkaline granitic series, are normally interpreted as representing the mantle component associated with the genesis of the granitoids. However, they rarely preserve the primitive character and therefore the establishment of the nature of this component as well as its homogeneity/heterogeneity during a tectonic event is difficult to establish. Although it is generally admitted 
that the ascent of mantle magmas in the continental crust creates a thermal anomaly which induces partial melting of different crustal levels, with consequent formation of granitic magmas, there is no unanimous opinion concerning various petrogenetic processes that lead to the formation of composite massifs, associating basic to intermediate rocks and granitoids.

In the Central Iberian Zone (CIZ), northern Portugal, large volumes of granitoids were emplaced during the post-collisional stage of the Hercynian orogeny (syn-to post-D3, the last ductile deformation phase). This was the main period of successive generation of granites (Ferreira et al., 1987a) which exhibit large compositional variability (Dias et al., 1998) as described below.

(1) Syn-D3 granitoids, 313-319 Ma: peraluminous biotite granodiorites to monzogranites and highly peraluminous two-mica leucogranites of calc-alkaline and aluminopotassic affinities;

(2) Late-D3 biotite-dominant granitoids, 306-311 Ma: mainly as composite massifs displaying a wide compositional range from gabbroic to granitic and a subalkaline affinity, being metaluminous to peraluminous. Other plutons exhibit characteristics of aluminopotassic associations;

(3) Late- to post-D3 granitoids, ca. 300 Ma: highly peraluminous, two-mica leucogranites of aluminopotassic affinity;

(4) Post-D3 granitoids, 290-296 Ma: slightly metaluminous to peraluminous monzogranites of subalkaline ferro-potassic affinity, occurring as zoned plutons.

Syn- and late-D3 biotite-rich granodiorites and monzogranites are the most abundant granitic rocks in the CIZ, spatially associated with mafic microgranular enclaves and minor bodies of basic to intermediate rocks. They represent an important period of Hercynian crustal growth and their origin is still a matter of debate (see Dias and Leterrier, 1994; Moreno-Ventas et al., 1995; Azevedo and Nolan, 1998; Villaseca et al., 1998; Bea et al., 1999; Castro et al., 1999; Menéndez and Ortega, 1999; Silva et al., 2000).

Several composite plutons in the CIZ (northern Portugal), which represent this type of granitoid, were selected for the mineralogical, chemical and $\mathrm{Sr}-\mathrm{Nd}$ isotopic study, complementing the earlier studies on the Braga pluton (Dias and Leterrier, 1994). They include coeval gabbro-norite to granodiorite stocks and/or mafic microgranular enclaves, which show evidence of interaction between felsic and mafic magmas. This presentation intends to provide constraints on the origin of these granitoids, as well as on the nature (homogeneity/ heterogeneity) of the parental reservoirs.

\section{Geology and Geochronology}

The studied granitic plutons are located in the CIZ northern Portugal, and their distribution is controlled by the Vigo-Régua ductile shear zone (Fig. 1). They are related to two different emplacement periods, relative to the third Hercynian tectonic phase: (1) syn-D3 biotite granitoids: Ucanha-Vilar, Lamego, Felgueiras, Sameiro and Refoios do Lima plutons; (2) late-D3 biotite-dominant granitoids: Braga pluton (Braga granite, associated gabbro to granodioritic bodies and Gonça granite), Agrela pluton and Celorico de Basto pluton (Celorico de Basto granite and associated gabbro to granodioritic stocks).

Syn-D3 biotite granitoids

This group is represented, from south to north, by the Ucanha-Vilar, Lamego, Felgueiras, Sameiro and Refoios do Lima plutons. The Ucanha-Vilar granite is spatially associated with hm-sized granodioritic stocks. Mafic microgranular enclaves occur dominantly in the Ucanha-Vilar, Lamego, Felgueiras and Sameiro plutons, decreasing in frequency from south to north, and become rare in the Refoios do Lima pluton. The granitic plutons present an essentially magmatic structure, marked by the orientation of K-feldspar phenocrysts and biotite. As proposed by Simões (2000), the fabric is the result of magma deformation by flattening with a reduced rotational component in a transpressive tectonic regime dominated by a NE-SW sub-horizontal compressive component, compatible with the D3 deformation phase. Based on structural and geological features, the plutons are considered early syn-D3 plutons. Zircon and monazite U-Pb geochronological data (Dias et al., 1998; Simões, 2000) from the Ucanha-Vilar, Lamego, Sameiro and Refoios do Lima granites show a narrow range of crystallization ages. between 313 and $321 \mathrm{Ma}$, yielding the almost concordant monazites very similar ages, $317 \pm 3 \mathrm{Ma}, 317 \pm 5 \mathrm{Ma}, 318 \pm 2 \mathrm{Ma}, 317 \pm 3 \mathrm{Ma}$, respectively (Table 1). The narrow range of age values is interpreted as representing an almost synchronous emplacement of the different plutons, at about $317 \mathrm{Ma}$. These age data are in agreement with a $\mathrm{K}-\mathrm{Ar}$ biotite age of $321 \pm 6 \mathrm{Ma}$ obtained by Martins (1997) for the Lamego granite. For the Ucanha-Vilar granite, available $\mathrm{K}-\mathrm{Ar}$ biotite ages in the range 294-306 Ma (Ferreira et al., 1987b) are interpreted as cooling ages.

\section{Late-D3 biotite-dominant granitoids}

This group is represented by the Braga, Agrela and Celorico de Basto plutons. They present magmatic structures (preferential orientation of K-feldspar phenocrysts and partially of biotite) in conformity with D3 fabric. 


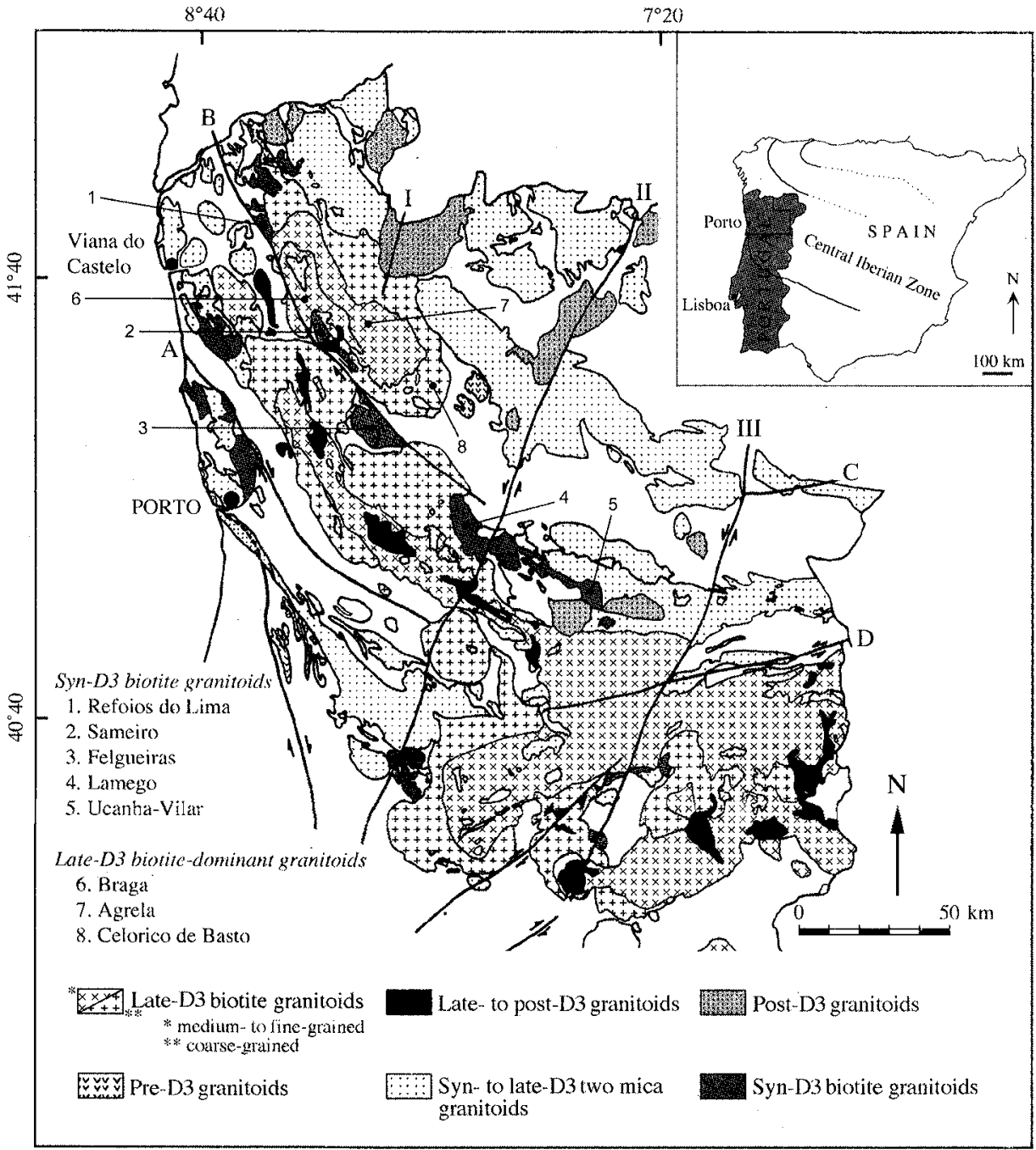

Fig. 1. Distribution of Hercynian syn- to post-orogenic granitoids in the Central Iberian Zone, northern Portugal (Ferreira et al., 1987 modified). A-"Sulco Carbonífero Dúrico-Beirão" shear zone, B-VigoRégua shear zone, C-MoncorvoBemposta shear zone, D-TraguntiaPenalva do Castelo shear zone, I-Gerês-Lovios fault, II-Régua-Verin fault, III-Vilariça fault, D3 - last ductile deformation phase.

The Braga massif is composite, associating two granitic units (Dias et al., 1992; Dias and Leterrier, 1994): the Braga granite which includes abundant mafic microgranular enclaves and hm-sized bodies of gabbroic to granodioritic rocks (gabbros, monzodiorites, quartz monzodiorites and granodiorites); the Gonça granite which is devoid of mafic rocks and contains mica-rich enclaves and metasedimentary xenoliths. The Braga biotite granodiorite/monzogranite is slightly porphyritic, fine- to medium-grained, and the biotite-muscovite Gonça monzogranite is fine-grained. The Agrela biotite granodiorite/monzogranite is porphyritic, mediumgrained and includes abundant mafic microgranular enclaves (Veloso, 1994; Veloso and Dias, 1995). The observed gradational contacts between the Braga-Gonça granites and Braga-Agrela granites, as well as the sharp but lobated contacts between the Braga granite and the basic to intermediate bodies, indicate a synchronous emplacement of the different plutonic units. Conventional
$\mathrm{U}-\mathrm{Pb}$ analysis of multi-grain zircon and monazite fractions, carried out (Dias et al., 1998) on four samples from the Braga, Gonça and Agrela granites and a quartz monzodiorite from the Braga composite pluton, have yielded similar ages in the range 307-311 Ma (Table 1). The narrow age range is in agreement with the geological interpretation (late-D3 emplacement) and indicates coeval emplacement of the four units. The U-Pb ages are concordant with the Rb-Sr whole-rock age of $310 \pm 10 \mathrm{Ma}$ and $307 \pm 10 \mathrm{Ma}$ obtained for the Braga and Agrela granites, respectively (Dias and Leterrier, 1993, 1994).

The Celorico de Basto pluton comprises the Celorico de Basto biotite monzogranite, containing rare mafic microgranular enclaves, which is spatially associated with $\mathrm{hm}$ - to $\mathrm{km}$-sized (maximum $3 \mathrm{~km}$ ) gabbroic to granodioritic bodies (Pereira, 1987; Helal, 1992). Detailed mapping (1:5000 scale) was undertaken on the bodies presenting greater petrographic variability (Carvalho, Carvalheira and Carvalho Velho sectors) (Fig. 2). They 


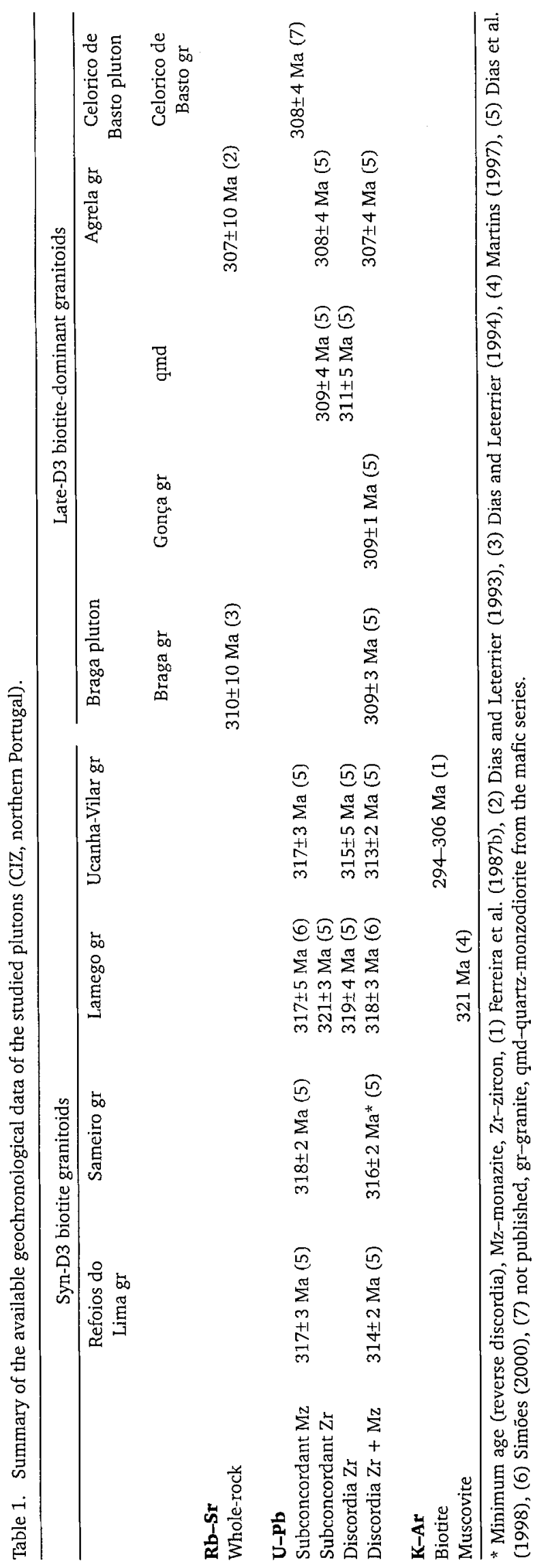



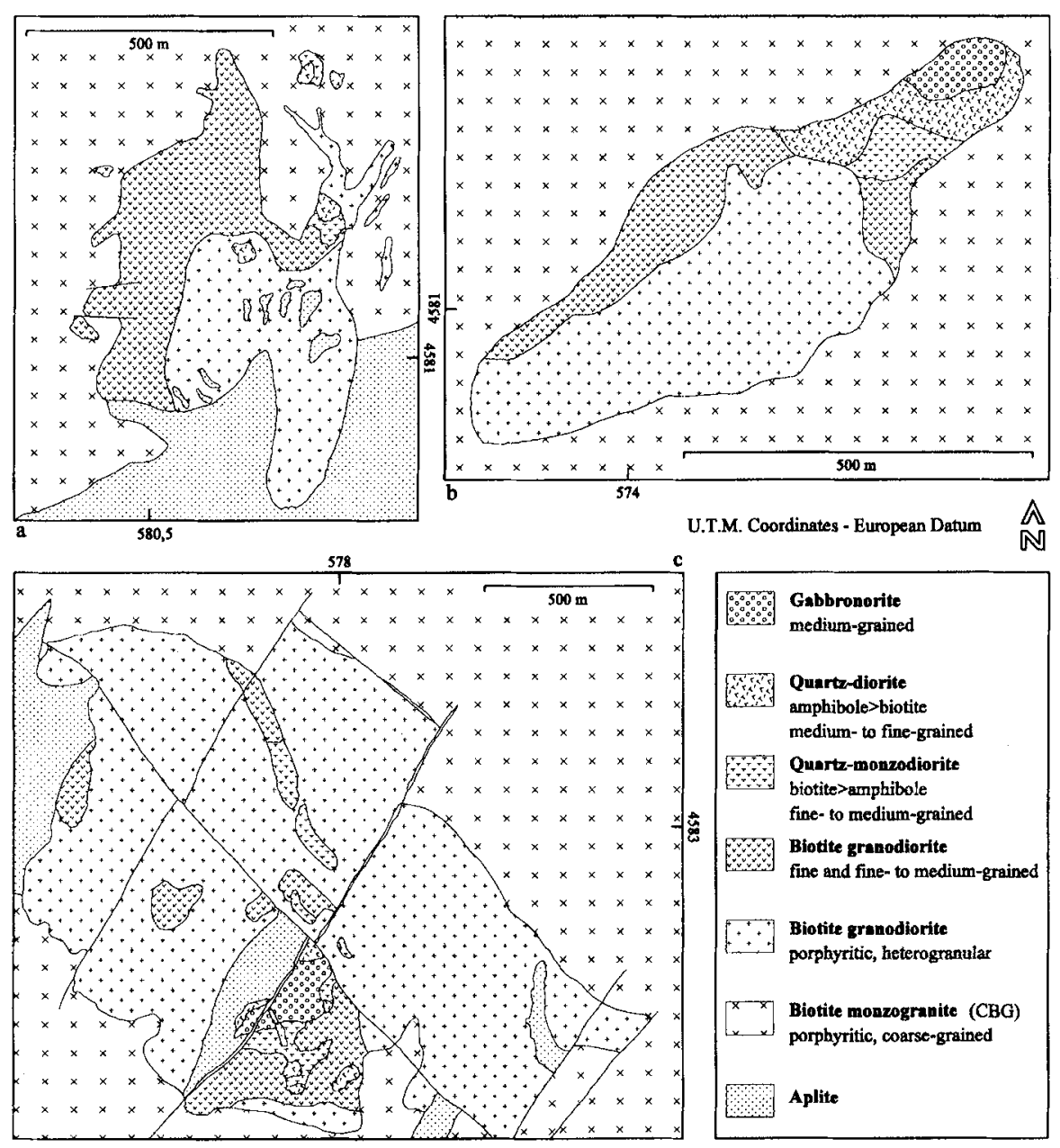

Fig. 2. Geological sketch maps of some gabbrogranodiorite stocks associated with the Celorico de Basto granite (CBG, northern Portugal). (a) Carvalho Velho stock, (b) Carvalheira stock, (c) Carvalho stock.

reveal a zoned structure, from gabbro to quartz-diorite, quartz-monzodiorite and granodiorite. The contact relationships are typically magmatic, with gradational or lobate and crenulate sharp contacts. The outermost facies is a porphyritic biotite granodiorite with a heterogranular groundmass (fine- and coarse-grained), that passes gradually to the host-rock, the Celorico de Basto biotite monzogranite. This is a porphyritic (K-feldspar phenocrysts) coarse-grained granite. The field observations reveal synchronous emplacement of different units that comprise the Celorico de Basto massif. U-Pb isotope analysis was undertaken for one fraction $(0.17 \mathrm{mg})$ of euhedral limpid monazite, extracted from one sample of Celorico de Basto monzogranite (unpublished data). The fraction is almost concordant $\left(-0.41 \%\right.$ discordancy) and provides a ${ }^{207} \mathrm{~Pb} /{ }^{235} \mathrm{U}$ age of $308 \pm 4 \mathrm{Ma}$, considered as the crystallization age of the granite. Due to the synchronous character of the different units of the Celorico de Basto massif, this result may be interpreted as representing the emplacement age of the massif, in the same age bracket of 306-311 Ma, proposed as the age of late-D3 plutonism in the CIZ by Dias et al. (1998). This age is also in accordance with the age results for equivalent granitic facies: Celeirós granite (Braga region), Rb-Sr $308 \pm 6 \mathrm{Ma}$ (Dias and Leterrier, 1993), U-Pb 306 $\pm 2 \mathrm{Ma}$ (Dias et al., 1998); Vieira do Minho granite, U-Pb $311 \pm 2 \mathrm{Ma}$ (Martins et al., 1999).

\section{Petrography and Mineralogy}

\section{Syn-D3 biotite granitoids}

The syn-D3 granitoids (Table 2) are porphyritic (euhedral orthoclase phenocrysts) medium-grained biotite granodiorites/monzogranites and contain quartz + plagioclase $\left(\mathrm{An}_{19-42}\right)+$ perthitic orthoclase + biotite + zircon + monazite + apatite + ilmenite \pm muscovite \pm allanite (+cordierite +sillimanite \pm garnet in the Refoios do Lima granite). The granodioritic bodies associated with the Ucanha-Vilar granite are fine-grained biotite-rich rocks that have compositions transitional between granodiorite and quartz-monzodiorite. They present the following 
Table 2. Normative compositions (estimated from whole-rock and mineral chemical composition) of the studied plutons (CIZ, northern Portugal).

\begin{tabular}{|c|c|c|c|c|c|c|c|c|c|}
\hline & $Q z$ & $\mathrm{Pl}(\% \mathrm{An})$ & $\mathrm{Kf}$ & $\mathrm{Mu}$ & $\mathrm{Bt}$ & $\mathrm{Hbl}$ & Cpy & Opy & $\mathrm{Ol}$ \\
\hline \multicolumn{10}{|c|}{ Syn-D3 biotite granitoids } \\
\hline Refoios do Lima gr & $23-30$ & $\begin{array}{c}31-36 \\
(19-39)\end{array}$ & $12-20$ & $4-6$ & $12-22$ & - & - & - & - \\
\hline Sameiro gr & $21-28$ & $\begin{array}{c}35-38 \\
(24-42)\end{array}$ & $17-25$ & $1-4$ & $14-18$ & - & - & - & - \\
\hline Felgueiras gr & $21-27$ & $\begin{array}{c}36-39 \\
(21-39)\end{array}$ & $15-21$ & $0-3$ & $14-22$ & - & - & - & - \\
\hline Lamego gr & $21-26$ & $\begin{array}{c}36-40 \\
(20-38)\end{array}$ & $16-22$ & $0-2$ & $15-20$ & - & - & - & - \\
\hline Ucanha-Vilar gr & $20-27$ & $\begin{array}{c}34-39 \\
(22-35)\end{array}$ & $19-26$ & $1-5$ & $10-20$ & - & - & - & - \\
\hline $\mathrm{gd}^{*}$ & $12-16$ & $\begin{array}{c}48-52 \\
(22-57)\end{array}$ & $8-10$ & - & $21-25$ & - & - & - & - \\
\hline \multicolumn{10}{|c|}{ Late-D3 biotite-dominant granitoids } \\
\hline \multicolumn{10}{|l|}{ Braga pluton } \\
\hline Gonça gr & $29-30$ & $\begin{array}{c}27-32 \\
(15-42)\end{array}$ & $22-29$ & $6-7$ & $6-11$ & - & - & - & - \\
\hline Braga gr & $22-28$ & $\begin{array}{c}28-36 \\
(19-36)\end{array}$ & $22-31$ & $0-4$ & $10-19$ & - & - & - & - \\
\hline ga & & $\begin{array}{c}52 \\
(54-64)\end{array}$ & - & - & 14 & 3 & 14 & 11 & 6 \\
\hline md & 9 & $\begin{array}{c}40 \\
(30-53)\end{array}$ & 11 & - & 20 & 16 & 2 & - & - \\
\hline qmd & 14 & $\begin{array}{c}39 \\
(35-44)\end{array}$ & 18 & - & 18 & 8 & 1 & - & - \\
\hline gd & 22 & $\begin{array}{c}35 \\
(17-41)\end{array}$ & 23 & - & 18 & - & - & - & - \\
\hline Agrela gr & $26-28$ & $\begin{array}{c}33-36 \\
(22-37)\end{array}$ & $19-23$ & $0-3$ & $13-17$ & - & - & - & - \\
\hline \multicolumn{10}{|l|}{ Celorico de Basto pluton } \\
\hline Celorico de Basto gr & $28-33$ & $\begin{array}{c}27-32 \\
(21-34)\end{array}$ & $21-29$ & $2-4$ & $10-12$ & - & - & - & - \\
\hline ga & - & $\begin{array}{c}52 \\
(50-66)\end{array}$ & - & - & 14 & 4 & 16 & 8 & 4 \\
\hline qd & 6 & $\begin{array}{c}36 \\
(26-42)\end{array}$ & 4 & - & 25 & 29 & - & - & - \\
\hline qma & 11 & $\begin{array}{c}43 \\
(31-53)\end{array}$ & 10 & - & 20 & 15 & - & - & - \\
\hline $\operatorname{gd}(1)$ & 23 & $\begin{array}{c}37 \\
(27-39)\end{array}$ & 14 & 1 & 23 & - & - & - & - \\
\hline$g d(2)$ & 26 & $\begin{array}{c}37 \\
(29-31)\end{array}$ & 19 & 1 & 17 & - & - & - & - \\
\hline
\end{tabular}

Data on Braga pluton are from Dias and Leterrier (1994). \% An from microprobe analysis; gr: granite; mafic series: gabbro (ga); quartz-diorite (qd); monzodiorite (md); quartz-monzodiorite (qmd); granodiorite (gd); * in spatial association with the Ucanha-Vilar granite; (1) fine-grained; (2) porphyritic with heterogranular groundmass; Qz: quartz; Pl: plagioclase; Kf: K-feldspar; Mu: muscovite; Bt: biotite; Hbl: hornblende; Cpy: clinopyroxene; Opy: orthopyroxene; Ol: olivine.

mineralogical association: quartz + plagioclase $\left(\mathrm{An}_{22-57}\right)$ + K-feldspar + biotite + apatite + zircon + ilmenite \pm allanite \pm titanite. The petrographic characteristics of the different granites and associated granodiorites are detailed in Simões (2000).

Biotites from different granites are aluminous $\left(\mathrm{Al}_{\text {total }}=\right.$ 3.01-3.54 apfu) and ferric ( $\left.X_{\mathrm{Mg}}=0.36-0.47\right)$, typical of biotites from calc-alkaline to aluminopotassic granites (Fig. 3). Biotite compositions show a continuous increase in $\mathrm{Al}_{\text {toral }}$ and decrease in $\mathrm{Mg}$ from southern to northern plutons, i.e., from the Ucanha-Vilar to the Refoios do Lima granites.
A morphological and geochemical study of zircon populations (Pupin, 1980, 1988, 1992, 1994) was undertaken by Simões (2000). The typology of zircon populations indicates that they are identical to zircon populations of calc-alkaline granites or aluminous monzogranites-granodiorites. For the Refoios do Lima granite, the typological evolutionary trend (TET) of zircon populations is typical of granites derived from crustal melts. For the other granites the TET cross the domain of the calc-alkaline granites to the crustal granites, in contrast with what would be expected from a simple evolutionary crystallization process. 


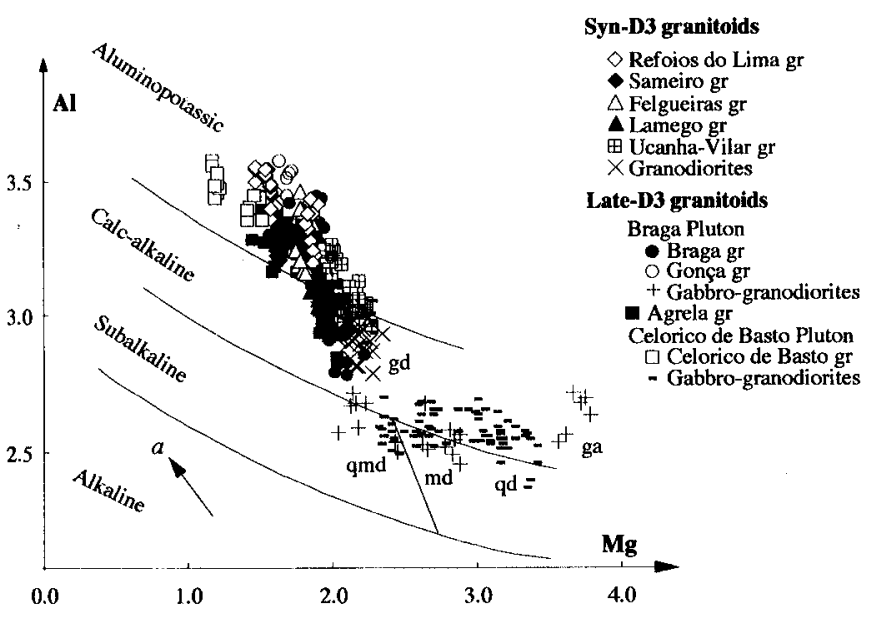

Fig. 3. $\mathrm{Al}_{\text {totul }}$ vs. $\mathrm{Mg}$ diagram (Nachit et al., 1985) for biotites of the studied syn- and late-D3 Hercynian granitic plutons (CIZ, northern Portugal). Fields of granitic biotites discriminated according to their host-rock magmatic type. Vector $a$ : evolution trend of biotites in relation to fractional crystallization process (Nachit et al., 1985). Data on Braga pluton are from Dias and Leterrier (1994). Granite (gr); mafic series: gabbro (ga); quartzdiorite (qd); monzodiorite (md); quartz-monzodiorite (qmd); granodiorite (gd). D3: last ductile deformation phase.

Electron microprobe analyses and observations on the internal structure enable the distinction of different stages in the evolutionary history of the zircon populations: an inherited phase, a magmatic phase and a late magmatic phase. In the Refoios do Lima granite, inherited zircon cores are abundant and the magmatic phase presents $\mathrm{HfO}_{2}$ $>1.2 \%$, predominance of $\mathrm{U}$ over $\mathrm{Th}$ and low $\mathrm{ThO}_{2}$ contents $(<0.5 \%)$. This is the signature of granites derived from crustal anatexis (Pupin, 1992, 1994). Zircons from the other granites reveal the following features: the magmatic phase presents a $\mathrm{HfO}_{2}$ compositional discontinuity and resorption structures between two magmatic stages; $\mathrm{HfO}_{2}$ $<1.2 \%$ and predominance of Th over $\mathrm{U}$ in the early magmatic stage, indicating a calc-alkaline signature; $\mathrm{HfO}_{2}$ $>1.2 \%$ in the later magmatic stage; rarity of the inherited phase. These features reveal the occurrence of a nonequilibrium stage and interaction during the magmatic evolution of initial calc-alkaline magmas. The late magmatic phase, rich in $\mathrm{Hf}$ and $\mathrm{U}$, is not very expressive in any of the granites, which indicates a $\mathrm{H}_{2} \mathrm{O}$ non-saturated character of the magmas.

\section{Late-D3 biotite-dominant granitoids}

The Braga, Gonça, Agrela and Celorico de Basto granodiorites-monzogranites present the following mineralogical association (Table 2): quartz + perthitic K-feldspar + plagioclase $\left(\mathrm{An}_{15-42}\right)+$ biotite (modal abundance 6-19\%) + muscovite (modal abundance $0-7 \%)+$ apatite + zircon + ilmenite + monazite $( \pm$ andalusite \pm sillimanite in the Gonça granite; \pm cordierite in the Celorico de Basto granite). The higher muscovite contents $(6-7 \%)$ are found in the Gonça monzogranite and the lower biotite contents (6-12\%) have been noticed in the Gonça and Celorico de Basto granites. These biotites are high- $\mathrm{Al}\left(\mathrm{Al}_{\text {total }}=3.35-3.57 \mathrm{apfu}\right)$ and low- $\mathrm{Mg}(\mathrm{Mg}=$ 1.18-1.74 apfu), typical of biotites from aluminopotassic associations (Fig. 3). Biotites from the Braga and Agrela granites are less aluminous $\left(\mathrm{Al}_{\text {total }}=2.78-3.44 \mathrm{apfu}\right)$ and more magnesian $(\mathrm{Mg}=1.46-2.23 \mathrm{apfu})$. For a detailed petrographic study of Braga, Gonça and Agrela granites see Veloso (1994).

The gabbroic rocks associated with the Braga and Celorico de Basto granites have similar petrographic characteristics. They are medium-grained gabbro-norites with labradorite $\left(\mathrm{An}_{50-66}\right)$, olivine $\left(\mathrm{Fo}_{63-72}\right)$, orthopyroxene (hypersthene-bronzite, $\mathrm{En}_{60-75}$ ), clinopyroxene (augite, $\mathrm{Wo}_{42-47}, \mathrm{En}_{41-47}$ ), magnesio-hornblende (according to Leake et al., 1997), phlogopite $\left(\mathrm{X}_{\mathrm{Mg}}=0.64-0.75\right)$, apatite, magnetite and ilmenite (Table 2). In the quartz-diorites, monzodiorites and quartz-monzodiorites, plagioclase is mainly andesine $\left(\mathrm{An}_{26-53}\right)$, orthopyroxene and olivine are absent and mafic minerals include amphibole (magnesiohornblende to actinolite), high-Mg biotite $\left(\mathrm{X}_{\mathrm{Mg}}=0.52-\right.$ $0.65)$ and accessory clinopyroxene $\left(\mathrm{Wo}_{46-50}, \mathrm{En}_{35-38}\right)$. They are melanocratic to mesocratic rocks, medium to finegrained, with predominance of amphibole over biotite in the quartzdioritic compositions. In the fine- to mediumgrained, sometimes porphyritic biotite granodiorites the dominant mafic mineral is biotite $\left(\mathrm{X}_{\mathrm{Mg}}=0.47-0.53\right)$ with rare amphibole (magnesio-hornblende). They are leucocratic with perthitic K-feldspar and plagioclase of oligoclase-andesine composition $\left(\mathrm{An}_{17-41}\right)$.

The evolution of biotite compositions from the Celorico de Basto composite pluton in the $\mathrm{Al}_{\text {total }} \mathrm{Vs}$. $\mathrm{Mg}$ diagram of Nachit et al. (1985) is marked by a two-step continuous trend, as pointed out by Dias and Leterrier (1994) for the Braga pluton (Fig. 3). Biotites from the less evolved rocks (gabbro, quartz diorite, monzodiorite and quartz monzodiorite) have similar compositions in the two plutons and show an evolution characterized by a sharp decrease in $\mathrm{Mg}$ whereas total $\mathrm{Al}$ has remained almost constant. In contrast, biotites from the granodiorites and from the host granites are distributed along an almost vertical trend (increase in $\mathrm{Al}$ whereas $\mathrm{Mg}$ remains almost constant). According to Nachit et al. (1985), the biotite compositions from a given plutonic association generated by fractional crystallization follow an oblique trend parallel to the vector $a$ in figure 3 (increase in $\mathrm{Al}_{\text {total }}$ and decrease in $\mathrm{Mg}$ ). Therefore, the observed biotite compositions rule out an origin by a simple fractional crystallization process for the Braga and Celorico de Basto plutons. 
Table 3. Major (\%) and trace (ppm) element composition of representative samples from the studied plutons (CIZ, northern Portugal).

\begin{tabular}{|c|c|c|c|c|c|c|c|c|c|c|c|c|c|}
\hline & \multirow{2}{*}{\multicolumn{2}{|c|}{ Refoios do Lina gr }} & \multicolumn{8}{|c|}{ Syn-D3 biotite granitoids } & \multicolumn{3}{|c|}{$\begin{array}{l}\text { Late-D3 biotite- } \\
\text { dominant granitoids }\end{array}$} \\
\hline & & & \multicolumn{2}{|c|}{ Sameiro gr } & \multicolumn{2}{|c|}{ Felgueiras gr } & \multicolumn{2}{|c|}{ Lamego gr } & \multicolumn{2}{|c|}{ Ucanha-Vilar gr } & \multirow{2}{*}{$\begin{array}{c}g^{*} * \\
14 B .7\end{array}$} & \multicolumn{2}{|c|}{$\begin{array}{c}\text { Braga pluton } \\
\text { Braga gr }\end{array}$} \\
\hline & $5 A .2$ & $1 \mathrm{C} .4$ & ST9.73 & ST9.70 & 9B.3 & $9 \mathrm{~B} .10$ & $14 \mathrm{~A} .2$ & 10C.1 & $14 \mathrm{~B} .2$ & $14 \mathrm{~B} .4$ & & A9.59 & A4.48 \\
\hline $\mathrm{SiO}_{2}$ & 62.25 & 69.56 & 66.70 & 67.55 & 62.84 & 66.39 & 62.96 & 66.56 & 62.14 & 68.90 & 57.94 & 64.96 & 69.03 \\
\hline $\mathrm{Al}_{2} \mathrm{O}_{3}$ & 16.88 & 15.01 & 15.86 & 15.53 & 16.42 & 15.51 & 16.28 & 15.13 & 16.35 & 15.21 & 17.33 & 15.13 & 14.34 \\
\hline $\mathrm{Fe}_{2} \mathrm{O}_{3} \mathrm{t}$ & 5.75 & 3.37 & 4.47 & 4.47 & 5.75 & 4.16 & 5.08 & 4.16 & 5.05 & 2.83 & 6.29 & 4.94 & 3.24 \\
\hline MnO & 0.06 & 0.03 & 0.07 & 0.07 & 0.07 & 0.05 & 0.05 & 0.06 & 0.06 & 0.03 & 0.08 & 0.07 & 0.06 \\
\hline $\mathrm{MgO}$ & 1.85 & 0.86 & 1.13 & 1.12 & 1.72 & 1.33 & 1.87 & 1.33 & 1.97 & 0.88 & 2.56 & 1.61 & 0.86 \\
\hline $\mathrm{CaO}$ & 2.70 & 1.54 & 2,41 & 2.00 & 3,12 & 2.58 & 3.29 & 2.49 & 3.32 & 1.70 & 4.08 & 2.77 & 1.61 \\
\hline $\mathrm{Na}_{2} \mathrm{O}$ & 2.95 & 3.50 & 3.15 & 3.22 & 2.99 & 3.07 & 3.00 & 3.08 & 3.06 & 3.32 & 3.89 & 2.95 & 3.00 \\
\hline $\mathrm{K}_{2} \mathrm{O}$ & 4.48 & 4.04 & 4.90 & 4.72 & 4.50 & 4.80 & 4.62 & 4.58 & 4.83 & 5.12 & 3.72 & 4.72 & 5.47 \\
\hline $\mathrm{TiO}_{2}$ & 0.81 & 0.44 & 0.56 & 0.58 & 0.80 & 0.56 & 0.69 & 0.58 & 0.64 & 0.39 & 1.01 & 0.96 & 0.66 \\
\hline $\mathrm{P}_{2} \mathrm{O}_{5}^{2}$ & 0.39 & 0.26 & 0.32 & 0.32 & 0.40 & 0.30 & 0.44 & 0.32 & 0.59 & 0.34 & 0.60 & 0.40 & 0.35 \\
\hline L.I. & 1.48 & 1.09 & 0.54 & 0.68 & 0.92 & 0.89 & 1.19 & 1.29 & 1.42 & 0.95 & 2.11 & 1.38 & 0.80 \\
\hline Total & 99.60 & 99.70 & 100.11 & 100.26 & 99.53 & 99.64 & 99.47 & 99.58 & 99.43 & 99.67 & 99.61 & 99.89 & 99.42 \\
\hline $\mathrm{Ba}$ & 1393 & 720 & 1362 & 1027 & 1662 & 1311 & 1715 & 1124 & 2006 & 939 & 1186 & 938 & 599 \\
\hline $\mathrm{Rb}$ & 183 & 263 & 210 & 241 & 179 & 224 & 176 & 196 & 201 & 228 & 161 & 252 & 361 \\
\hline $\mathrm{Sr}$ & 451 & 252 & 435 & 317 & 531 & 444 & 675 & 403 & 896 & 425 & 583 & 299 & 176 \\
\hline $\mathrm{Cr}$ & 50 & 30 & 22 & 33 & 28 & 20 & 28 & 25 & 28 & 24 & 57 & 28 & 10 \\
\hline $\mathrm{Zr}$ & 300 & 171 & 232 & 214 & 288 & 203 & 253 & 194 & 261 & 188 & 260 & 308 & 209 \\
\hline Y & 26 & 15 & 22 & 33 & 29 & 20 & 25 & 27 & 22 & 14 & 23 & 28 & 23 \\
\hline La & 139.80 & 77.45 & 86.65 & 111.35 & 156.22 & 99.45 & 141.76 & 103.31 & 166.75 & 92.84 & 87.29 & 71.31 & 55.81 \\
\hline $\mathrm{Ce}$ & 251.37 & 135.31 & 181.82 & 210.92 & 261.82 & 171.74 & 253.32 & 175.37 & 282.02 & 173.79 & 157.70 & 146.18 & 119.58 \\
\hline $\mathrm{Nd}$ & 98.11 & 56.03 & 55.63 & 80.15 & 107.08 & 71.05 & 102.17 & 75.12 & 115.86 & 66.43 & 67.38 & 60.62 & 45.59 \\
\hline $\mathrm{Sm}$ & 15.17 & 8.27 & 8.92 & 12.86 & 16.64 & 11.33 & 15.80 & 11.98 & 16.89 & 10.86 & 10.30 & 10.63 & 8.86 \\
\hline Eu & 2.54 & 1.43 & 1.56 & 1.90 & 3.00 & 2.15 & 2.88 & 2.12 & 3.32 & 1.66 & 2.25 & 1.59 & 1.24 \\
\hline $\mathrm{Gd}$ & 10.36 & 5.43 & 6.68 & 8.55 & 10.71 & 7.42 & 10.35 & 8.02 & 10.85 & 7.38 & 7.71 & 7.33 & 6.28 \\
\hline Dy & 5.48 & 3.42 & 3.52 & 5.29 & 5.90 & 4.25 & 5.39 & 4.93 & 4.98 & 3.34 & 4.82 & 4.77 & 4.54 \\
\hline $\mathrm{Er}$ & 2.27 & 1.16 & 1.84 & 2.97 & 2.56 & 1.96 & 2.16 & 2.17 & 1.80 & 1.40 & 2.28 & 2.32 & 2.06 \\
\hline Yb & 2.02 & 1.21 & 1.61 & 3.02 & 2.32 & 1.79 & 1.91 & 2.12 & 1.44 & 1.12 & 1.88 & 1.96 & 1.76 \\
\hline Lu & 0.27 & 0.14 & 0.36 & 0.51 & 0.32 & 0.25 & 0.26 & 0.30 & 0.18 & 0.17 & 0.28 & 0.30 & 0.20 \\
\hline
\end{tabular}

\section{Geochemistry}

Representative whole-rock chemical compositions from different units of the studied plutons are given in table 3 . All the analyzed samples are plotted on variation diagrams of selected major and trace elements vs. $\mathrm{Fe}+\mathrm{Mg}+\mathrm{Ti}$ parameter (calculated in millications per $100 \mathrm{~g}$ of rock and proportional to its mafic mineral content) used as a differentiation index (Fig. 4). Figure 5 shows the chondritenormalized REE patterns of the representative samples.

$\mathrm{Sr}$ and $\mathrm{Nd}$ isotopic data are given in table 4. Accounting for the geochronological data and for field data showing the synchronous emplacement of the different units from each composite pluton, the ${ }^{87} \mathrm{Sr} /{ }^{86} \mathrm{Sr}$ initial ratios and $\mathrm{ENd}_{\mathrm{CHUR}}$ values were calculated for the following ages: syn-D3 granitoids, $317 \mathrm{Ma}$; late-D3 granitoids, $310 \mathrm{Ma}$, $307 \mathrm{Ma}$ and $308 \mathrm{Ma}$ for Braga, Agrela and Celorico de Basto plutons.

\section{Major and trace elements}

Syn-D3 biotite granitoids

The syn-D3 granitoids included in this study are slightly to moderately peraluminous $[\mathrm{A}=\mathrm{Al}-(\mathrm{K}+\mathrm{Na}+2 \mathrm{Ca})=$
$0-45$; Fig. 4]. The lowest values of the A parameter are found in the Ucanha-Vilar granite and the Refoios do Lima granite is distinctly peraluminous $(A=34-45)$. In general, an increase in the peraluminous character is observed from the southern to northern plutons, i.e., from the UcanhaVilar to the Refoios do Lima granites. The $\mathrm{SiO}_{2}$ content ranges from 62 to $70 \%$ and noteworthy characteristics of these granitoids are: rather high $\mathrm{Ba}(720-2181 \mathrm{ppm})$ and REE (La $=77-167 \mathrm{ppm})$ contents; highly fractionated REE patterns $\left(\mathrm{La}_{\mathrm{N}} / \mathrm{Yb}_{\mathrm{N}}=32-78\right]$; and moderate negative Eu anomalies (Eu/Eu* $=0.52-0.72)$ (Figs. 4 and 5).

Differences in the chemical composition are evident between the Ucanha-Vilar and the Refoios do Lima granites and, in general, the other granites have an intermediate composition. For the same values of the parameter $\mathrm{Fe}+\mathrm{Mg}+\mathrm{Ti}$, the Ucanha-Vilar granite shows higher $\mathrm{Ca}, \mathrm{Mg}, \mathrm{P}, \mathrm{Ba}, \mathrm{Sr}, \mathrm{REE}, \mathrm{La}_{\mathrm{N}} / \mathrm{Yb}_{\mathrm{N}}$ and lower $\mathrm{Fe}$.

Both mineralogical and whole-rock data show that all the four plutons define separate evolutionary trends (Simões, 2000). The whole-rock chemical evolutions are characterized by a decrease in $\mathrm{Al}, \mathrm{Ca}, \mathrm{P}, \mathrm{Ba}, \mathrm{Sr}, \mathrm{Zr}, \mathrm{Y}, \mathrm{La}$ and $\mathrm{La}_{\mathrm{N}} / \mathrm{Yb}_{\mathrm{N}}$, and an increase in $\mathrm{Si}$ and $\mathrm{Na}$ with the decrease of the $\mathrm{Fe}+\mathrm{Mg}+\mathrm{Ti}$ parameter. The Sameiro pluton is an exception and does not show significant chemical evolution. 


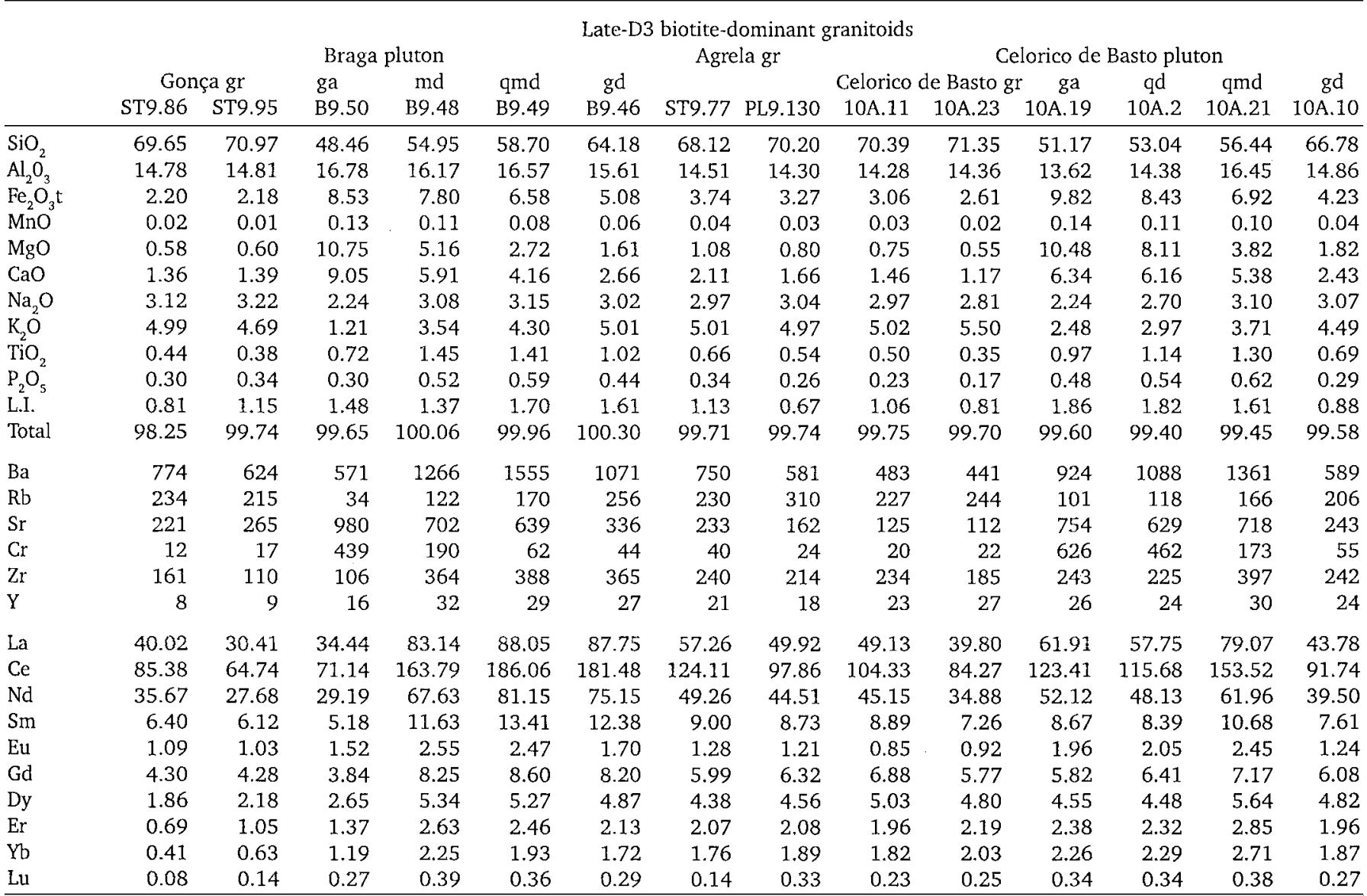

Analytical methods: Major and trace elements determined by ICP-AES and ICP-MS (CRPG-CNRS, Nancy; France). Analytical uncertainties are estimated at $2 \%$ for major elements and at $5 \%$ or $10 \%$ for trace-element concentrations (except REE) higher or lower than 20 ppm, respectively. Precision for REE is estimated at 5\% when chondritic-normalized concentrations are $<10$ and at $10 \%$ when they are lower. Data on Braga pluton are from Dias and Leterrier (1994). $\mathrm{Fe}_{2} \mathrm{O}_{3} \mathrm{t}=$ total iron; L.I. = loss on ignition; granite(gr); mafic series; gabbro (ga); quartz-diorite (qd); monzodiorite (md); quartz-monzodiorite (qmd); granodiorite (gd); * in spatial association with the Ucanha-Vilar granite.

The granodiorites from the mafic bodies associated with the Ucanha-Vilar granite are slightly metaluminous (A from -11 to 1) and have higher $\mathrm{Al}, \mathrm{Ca}, \mathrm{Na}, \mathrm{Fe}, \mathrm{Mg}, \mathrm{Ti}, \mathrm{Zr}$, $\mathrm{Y}$ and lower $\mathrm{Si}, \mathrm{K}, \mathrm{Rb}$ contents in comparison to the granite (Fig. 4).

The data reveal lack of geochemical continuity among all the granitoids, indicating that the hypothesis of various intrusive units originated from magmas with distinct compositions that evolved independently must be envisaged.

\section{Late-D3 biotite-dominant granitoids}

Different units of the Braga and Celorico de Basto plutons display a wide compositional range $\left(\mathrm{SiO}_{2}=48.5-\right.$ $71.4 \%, \mathrm{MgO}=0.6-12.4 \%, \mathrm{CaO}=1.2-9.1 \%)$. The basic to intermediate series are dominantly metaluminous, reaching $A=-102$ for gabbroic rocks (Fig. 4). The Braga granite reveals a slightly peraluminous character $(A=0-32)$ and the Gonça and Celorico de Basto granites are moderately peraluminous $(A=25-52)$. As it was previously evidenced for the Braga pluton (Dias and Leterrier, 1994), the Celorico de Basto pluton presents an evolutionary chemical continuity, without significant compositional gaps, from gabbro to the granite. This continuous evolution indicates a genetic link between different units of each pluton. With the decrease in the $\mathrm{Fe}+\mathrm{Mg}+\mathrm{Ti}$ parameter, three types of evolution are observed in the two plutons: (i) increase of $\mathrm{Si}, \mathrm{Na}, \mathrm{K}$ and $\mathrm{Rb}$ contents; (ii) decrease of $\mathrm{Ca}, \mathrm{Sr}, \mathrm{Cr}$ and $\mathrm{Eu} / \mathrm{Eu}^{*}$; (iii) curvilinear trends with initial increase (for the basic to intermediate compositions) and later decrease in $\mathrm{Ti}, \mathrm{Ba}$, $\mathrm{Zr}$ and La (Figs. 4 and 5). On the R1-R2 diagram (La Roche et al., 1980) different units of the Braga and Celorico de Basto series are distributed in the subalkaline domain, along regular curves with a curvature to quartzmonzodiorite compositions. Such evolutionary trends are typical of subalkaline (monzonitic) associations and identical to the trend observed in the plutonic series of 

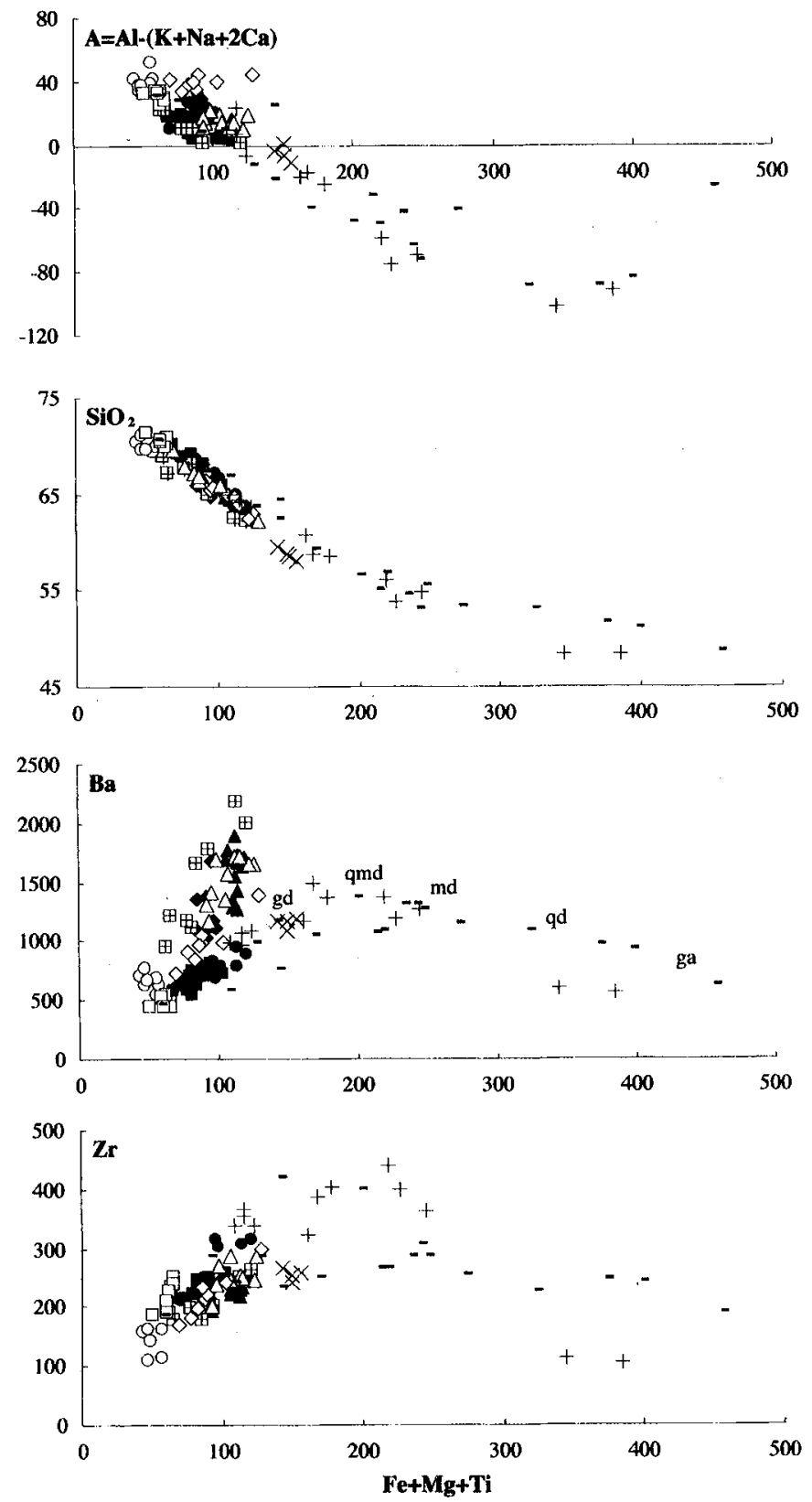

Fig. 4. Variation diagrams of selected major (\%) and trace (ppm) elements and $\mathrm{Al}-(\mathrm{K}+\mathrm{Na}+2 \mathrm{Ca})$ vs. $\mathrm{Fe}+\mathrm{Mg}+\mathrm{Ti}$ for the studied plutons (these two chemical-mineralogical parameters are in millications per $100 \mathrm{~g}$ of rock; $\mathrm{Fe}+\mathrm{Mg}+\mathrm{Ti}$ is proportional to the mafic content of the rock). Mafic series: gabbro (ga), quartzdiorite (q́d), monzodiorite (md), quartz-monzodiorite (qmd), granodiorite (gd). Legend as in figure 3.

the Ballons massif (Vosges, France; Pagel and Leterrier, 1980). These curvilinear trends may be explained by a process of mineral fractionation, with significant variation in mineral phases that fractionate (from calcium-rich plagioclase + olivine + orthopyroxene + clinopyroxene to more sodic plagioclase + amphibole + biotite + zircon) at different evolution stages of the plutonic series.
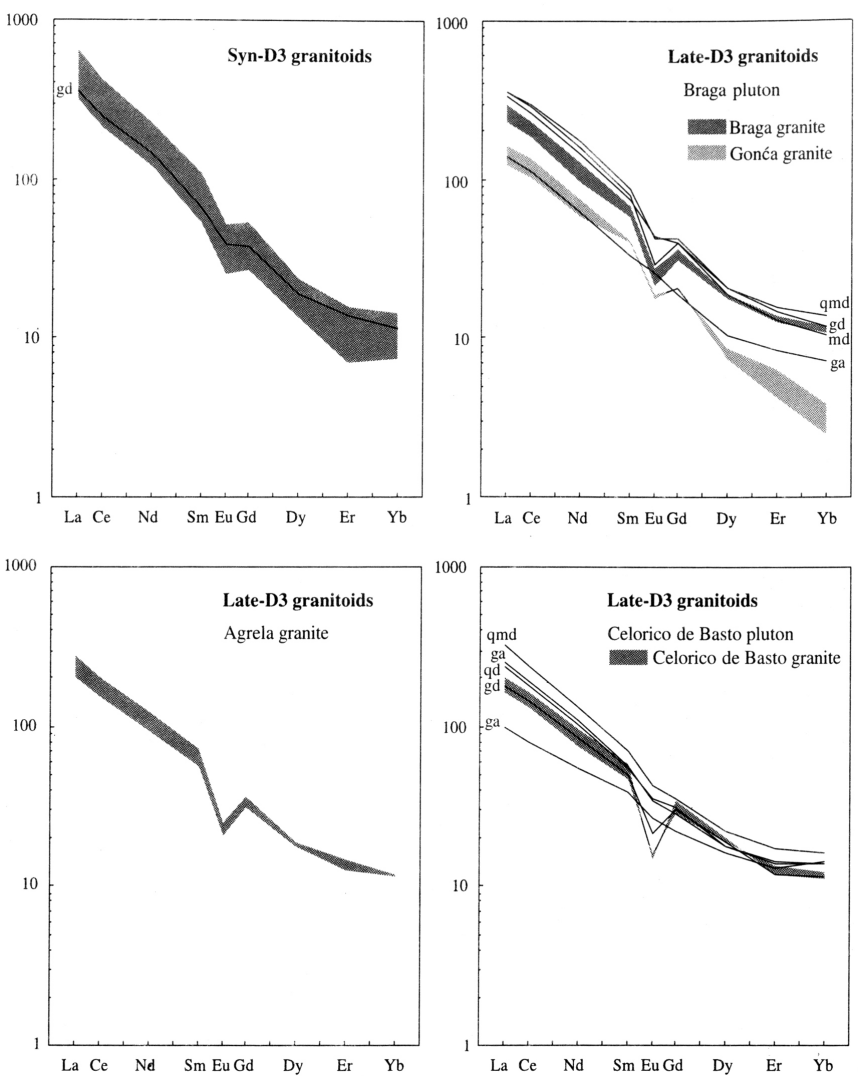

Fig. 5. Chondrite-normalized REE patterns for the studied syn- and late-D3 Hercynian granitic plutons (CIZ, northern Portugal). REE normalization values from Evensen et al. (1978). Mafic series: gabbro (ga), quartz-diorite (qd), monzodiorite (md), quartz-monzodiorite (qmd), granodiorite (gd).

The gabbro-norite from the two series show a primitive character $[(\mathrm{Mg} /(\mathrm{Fe}+\mathrm{Mg})=0.68-0.72$ and $\mathrm{Cr}=439-$ $626 \mathrm{ppm}]$ and has a chemical signature typical of shoshonitic basalts (Pearce, 1982), characterized by higher contents of $\mathrm{Al}, \mathrm{K}, \mathrm{Ba}, \mathrm{Sr}, \mathrm{Th}$ and LREE and distinctive low Ti, Nb and HREE contents (Table 3 ). A similar pattern is also displayed by the gabbro from the plutonic series of the monzonitic Ballons massif in France (Pagel and Leterrier, 1980).

Comparing the two granitic units of the Braga pluton, the Gonça monzogranite presents lower contents in compatible elements such as Ti, Zr, Y and REE (mainly HREE) as well as steeper REE patterns $\left(\mathrm{La}_{N} / \mathrm{Yb}_{\mathrm{N}}=33-\right.$ 66) (Table 3, Figs. 4 and 5). The Agrela granite is identical to the Braga granite in both mineralogical and chemical composition (Table 2 and 3, Figs. 3, 4 and 5). The geochemical data rule out any compositional relation of these granites with the Celorico de Basto granite, which is comparatively enriched in $\mathrm{Si}$ and depleted in $\mathrm{Ca}, \mathrm{Fe}$, $\mathrm{Mg}, \mathrm{Ti}, \mathrm{Sr}, \mathrm{Ba}$ and REE, with less fractionated REE patterns. 
Table 4. Sr and Nd isotopic data for the studied plutons (CIZ, northern Portugal).

\begin{tabular}{|c|c|c|c|c|c|c|c|c|c|c|c|}
\hline & $\begin{array}{r}\mathrm{Rb} \\
\mathrm{ppm}\end{array}$ & $\begin{array}{r}\mathrm{Sr} \\
\mathrm{ppm}\end{array}$ & ${ }^{87} \mathrm{Rb} /{ }^{86} \mathrm{Sr}$ & $\begin{array}{l}{ }^{87} \mathrm{Sr} /{ }^{86} \mathrm{Sr} \\
\quad \pm 2 \sigma\end{array}$ & $\left({ }^{87} \mathrm{Sr} /{ }^{86} \mathrm{Sr}\right)$ & $\begin{array}{r}\text { Sm } \\
\text { ppm }\end{array}$ & $\begin{array}{r}\mathrm{Nd} \\
\mathrm{ppm}\end{array}$ & ${ }^{147} \mathrm{Sm} /{ }^{144} \mathrm{Nd}$ & $\begin{array}{r}{ }^{143} \mathrm{Nd} /{ }^{144} \mathrm{Nd} \\
\quad \pm 2 \sigma\end{array}$ & $\varepsilon \mathrm{Nd}$ & $\underset{\mathrm{GM}}{\mathrm{T}_{\mathrm{DM}}}$ \\
\hline \multicolumn{12}{|c|}{$\begin{array}{l}\text { Syn-D3 biotite granitoids } \\
\text { Refoios do Lima gr }\end{array}$} \\
\hline 1C. 4 & $255^{\circ}$ & 238 & 3.101 & $\begin{array}{r}0.724367 \\
\pm 15\end{array}$ & 0.7104 & 8.31 & 55.78 & $\begin{array}{r}0.0900 \\
\pm 14\end{array}$ & 0.512095 & -6.28 & 1.43 \\
\hline $5 \mathrm{~A} .2$ & 178 & 434 & 1.189 & $\begin{array}{r}0.715939 \\
\pm 22\end{array}$ & 0.7106 & 14.63 & 101.90 & $\begin{array}{r}0.0868 \\
\pm 12\end{array}$ & 0.512102 & -6.01 & 1.41 \\
\hline $5 A .4$ & 213 & 268 & 2.301 & $\begin{array}{r}0.720853 \\
\pm 14\end{array}$ & 0.7105 & 8.64 & 57.85 & $\begin{array}{r}0.0903 \\
\pm 14\end{array}$ & 0.512109 & -6.01 & 1.41 \\
\hline \multicolumn{12}{|c|}{ Sameiro gr } \\
\hline B4.34 & 204 & 483 & 1.220 & $\begin{array}{r}0.713904 \\
\pm 19\end{array}$ & 0.7084 & 11.80 & 84.20 & $\begin{array}{r}0.0850 \\
\pm 12\end{array}$ & 0.512171 & -4.59 & 1.30 \\
\hline ST9.70 & 234 & 307 & 2.200 & $\begin{array}{r}0.718275 \\
\pm 28\end{array}$ & 0.7083 & 11.90 & 81.90 & $\begin{array}{r}0.0882 \\
\pm 23\end{array}$ & 0.512155 & -5.03 & 1.33 \\
\hline \multicolumn{12}{|c|}{ Felgueiras gr } \\
\hline $9 \mathrm{~B} . \overline{3}$ & 190 & 546 & 1.010 & $\begin{array}{r}0.712913 \\
\pm 14\end{array}$ & 0.7084 & 13.76 & 88.55 & $\begin{array}{r}0.0946 \\
\pm 19\end{array}$ & 0.512148 & -5.43 & 1.36 \\
\hline 9B.7 & 203 & 462 & 1.275 & $\begin{array}{r}0.714014 \\
\pm 24\end{array}$ & 0.7083 & 13.21 & 90.71 & $\begin{array}{r}0.0880 \\
\pm 6\end{array}$ & 0.512152 & -5.08 & 1.34 \\
\hline $\begin{array}{l}9 B .10 \\
\text { Lamegc }\end{array}$ & 198 & 414 & 1.386 & $\begin{array}{r}0.714564 \\
\pm 20\end{array}$ & 0.7083 & 9.84 & 66.87 & $\begin{array}{r}0.0890 \\
\pm 15\end{array}$ & 0.512157 & -5.02 & 1.33 \\
\hline $10 \mathrm{C} .1$ & 225 & 395 & 1.647 & $\begin{array}{r}0.715860 \\
\pm 20\end{array}$ & 0.7084 & 10.59 & 68.23 & $\begin{array}{r}0.0938 \\
\pm 8\end{array}$ & 0.512164 & -5.09 & 1.34 \\
\hline $10 \mathrm{C} .2$ & 212 & 517 & 1.189 & $\begin{array}{r}0.713863 \\
\pm 16\end{array}$ & 0.7085 & 9.95 & 80.08 & $\begin{array}{r}0.0752 \\
\pm 5\end{array}$ & 0.512128 & -5.03 & 1.33 \\
\hline $14 \mathrm{~A} .2$ & 197 & 695 & 0.820 & $\begin{array}{r}0.711945 \\
\pm 14\end{array}$ & 0.7082 & 14.70 & 98.39 & $\begin{array}{r}0.0903 \\
\pm 6\end{array}$ & 0.512159 & -5.04 & 1.33 \\
\hline \multicolumn{12}{|c|}{ Ucanha-Vilar gr } \\
\hline 14B.2 & 227 & 866 & 0.758 & $\begin{array}{r}0.710624 \\
\pm 16\end{array}$ & 0.7072 & 15.94 & 112.83 & $\begin{array}{r}0.0854 \\
\pm 13\end{array}$ & 0.512182 & -4.39 & 1.28 \\
\hline $14 \mathrm{~B} .4$ & 251 & 392 & 1.853 & $\begin{array}{r}0.715547 \\
\pm 32\end{array}$ & 0.7072 & 9.76 & 65.03 & $\begin{array}{r}0.0908 \\
\pm 17\end{array}$ & 0.512175 & -4.75 & 1.31 \\
\hline 14D.1 & 219 & 568 & 1.117 & $\begin{array}{r}0.712389 \\
\pm 20\end{array}$ & 0.7073 & 11.51 & 76.54 & $\begin{array}{r}0.0909 \\
\pm 6\end{array}$ & 0.512186 & -4.54 & 1.30 \\
\hline \multicolumn{12}{|c|}{ Granodiorites* } \\
\hline $14 \mathrm{~B} .7$ & 166 & 596 & 0.805 & $\begin{array}{r}0.710035 \\
\pm 18\end{array}$ & 0.7064 & 9.46 & 61.62 & $\begin{array}{r}0.0928 \\
\pm 5\end{array}$ & 0.512253 & -3.31 & 1.20 \\
\hline $14 \mathrm{~B} .9$ & 157 & 611 & 0.742 & $\begin{array}{r}0.709705 \\
\pm 17\end{array}$ & 0.7064 & 8.15 & 51.21 & $\begin{array}{r}0.0962 \\
\pm 9\end{array}$ & 0.512258 & -3.35 & 1.20 \\
\hline 14B. 10 & 168 & 566 & 0.858 & $\begin{array}{r}0.7102 .50 \\
\pm 17\end{array}$ & 0.7064 & 9.18 & 64.99 & $\begin{array}{r}0.0857 \\
\pm 10\end{array}$ & 0.512239 & -3.29 & 1.20 \\
\hline \multicolumn{12}{|c|}{$\begin{array}{l}\text { Late-D3 biotite-dominant granitoids } \\
\text { Braga pluton }\end{array}$} \\
\hline $\begin{array}{l}\text { Braga gr } \\
\text { A4.48 }\end{array}$ & 318 & 202 & 4.560 & $\begin{array}{r}0.727334 \\
\pm 19\end{array}$ & 0.7072 & 7.42 & 42.67 & $\begin{array}{r}0.1052 \\
\pm 20\end{array}$ & 0.512149 & -5.96 & 1.40 \\
\hline A4.50 & 271 & 241 & 3.253 & $\begin{array}{r}0.721670 \\
\pm 21\end{array}$ & 0.7073 & 8.98 & 55.11 & $\begin{array}{r}0.0986 \\
\pm 10\end{array}$ & 0.512123 & -6.20 & 1.41 \\
\hline $\mathrm{A} 4.53$ & 270 & 280 & 2.785 & $\begin{array}{r}0.719422 \\
\pm 17\end{array}$ & 0.7071 & 9.17 & 56.70 & $\begin{array}{r}0.0977 \\
\pm 8\end{array}$ & 0.512162 & -5.37 & 1.35 \\
\hline A9.59 & 234 & 289 & 2.341 & $\begin{array}{r}0.717614 \\
\pm 19\end{array}$ & 0.7073 & 9.74 & 59.70 & $\begin{array}{r}0.0986 \\
\pm 10\end{array}$ & 0.512165 & -5.39 & 1.35 \\
\hline $\begin{array}{l}\text { Gonça g } \\
\text { ST9.86 }\end{array}$ & 235 & 208 & 3.261 & $\begin{array}{r}0.723712 \\
\pm 21\end{array}$ & 0.7093 & 6.55 & 36.01 & $\begin{array}{r}0.1099 \\
\pm 8\end{array}$ & 0.512115 & -6.81 & 1.46 \\
\hline \multicolumn{12}{|c|}{ Mafic series } \\
\hline B9.46 & 242 & 325 & 2.154 & $\begin{array}{r}0.716540 \\
\pm 27\end{array}$ & 0.7070 & 11.68 & 74.22 & $\begin{array}{r}0.0951 \\
\pm 8\end{array}$ & 0.512157 & -5.40 & 1.35 \\
\hline B9.48 & 123 & 688 & 0.517 & $\begin{array}{r}0.707604 \\
\pm 19\end{array}$ & 0.7053 & 9.58 & 60.53 & $\begin{array}{r}0.0957 \\
\pm 11\end{array}$ & 0.512283 & -2.97 & 1.17 \\
\hline B9.49 & 163 & 626 & 0.754 & $\begin{array}{r}0.709441 \\
\pm 18\end{array}$ & 0.7056 & 12.10 & 77.31 & $\begin{array}{r}0.0947 \\
\pm 16\end{array}$ & 0.512201 & -4.52 & 1.29 \\
\hline B9. 50 & 34.7 & 978 & 0.102 & $\begin{array}{r}0.705422 \\
\pm 17\end{array}$ & 0.7050 & 4.56 & 28.20 & $\begin{array}{r}0.0978 \\
\pm 15\end{array}$ & 0.512312 & -2.48 & 1.13 \\
\hline
\end{tabular}


Table 4. Contd.

\begin{tabular}{|c|c|c|c|c|c|c|c|c|c|c|c|}
\hline & $\begin{array}{r}\mathrm{Rb} \\
\mathrm{ppm}\end{array}$ & $\begin{array}{r}\mathrm{Sr} \\
\mathrm{ppm}\end{array}$ & ${ }^{87} \mathrm{Rb} /{ }^{86} \mathrm{Sr}$ & $\begin{array}{l}{ }^{87} \mathrm{Sr} /{ }^{86} \mathrm{Sr} \\
\quad \pm 2 \sigma\end{array}$ & $\left({ }^{87} \mathrm{Sr} /{ }^{86} \mathrm{Sr}\right){ }_{i}$ & $\begin{array}{r}\mathrm{Sm} \\
\mathrm{ppm}\end{array}$ & $\begin{array}{r}\mathrm{Nd} \\
\mathrm{ppm}\end{array}$ & ${ }^{147} \mathrm{Sm} /{ }^{144} \mathrm{Nd}$ & $\begin{aligned}{ }^{143} \mathrm{Nd} & /{ }^{144} \mathrm{Nd} \\
& \pm 2 \sigma\end{aligned}$ & $\varepsilon \mathrm{Nd}$ & $\begin{array}{r}\mathrm{T}_{\mathrm{DM}} \\
\mathrm{Ga}\end{array}$ \\
\hline \multicolumn{12}{|c|}{ Agrela gr } \\
\hline B9.58 & 261 & 233 & 3.251 & $\begin{array}{r}0.720803 \\
\pm 15\end{array}$ & 0.7066 & 8.69 & 52.17 & 0.1007 & $\begin{array}{r}0.512190 \\
\pm 8\end{array}$ & -4.98 & 1.32 \\
\hline PL9.109 & 317 & 171 & 5.362 & $\begin{array}{r}0.729861 \\
\pm 15\end{array}$ & 0.7064 & 7.01 & 40.02 & 0.1059 & $\begin{array}{r}0.512192 \\
\pm 8\end{array}$ & -5.15 & 1.33 \\
\hline PL9.130 & 305 & 152 & 5.805 & $\begin{array}{r}0.732505 \\
\pm 15\end{array}$ & 0.7071 & 7.55 & 39.97 & 0.1142 & $\begin{array}{r}0.512173 \\
\pm 9\end{array}$ & -5.84 & 1.39 \\
\hline ST9.77 & 281 & 221 & 3.690 & $\begin{array}{r}0.723129 \\
\pm 10\end{array}$ & 0.7070 & 8.00 & 47.22 & 0.1031 & $\begin{array}{r}0.512183 \\
\pm 7\end{array}$ & -5.21 & 1.34 \\
\hline ST9.83 & 304 & 202 & 4.361 & $\begin{array}{r}0.726263 \\
\pm 16\end{array}$ & 0.7072 & 7.70 & 45.49 & 0.1030 & $\begin{array}{r}0.512148 \\
\pm 6\end{array}$ & -5.89 & 1.39 \\
\hline ST9.118 & 278 & 205 & 3.929 & $\begin{array}{r}0.724670 \\
\pm 14\end{array}$ & 0.7075 & 7.77 & 45.79 & 0.1026 & $\begin{array}{r}0.512144 \\
\pm 9\end{array}$ & -5.96 & 1.39 \\
\hline \multicolumn{12}{|c|}{$\begin{array}{l}\text { Celorico de Basto pluton } \\
\text { Celorico de Basto gr }\end{array}$} \\
\hline 10A.11 & 249 & 105 & 6.881 & $\begin{array}{r}0.739082 \\
\pm 20\end{array}$ & 0.7089 & 8.13 & 42.51 & 0.1156 & $\begin{array}{r}0.512185 \\
\pm 9\end{array}$ & -5.66 & 1.37 \\
\hline 10A. 23 & 261 & 119 & 6.364 & $\begin{array}{r}0.736903 \\
\pm 18\end{array}$ & 0.7090 & 6.67 & 33.27 & 0.1211 & $\begin{array}{r}0.512198 \\
\pm 9\end{array}$ & -5.62 & 1.37 \\
\hline \multicolumn{12}{|c|}{ Mafic series } \\
\hline $10 \mathrm{~A} .1$ & 174 & 541 & 0.933 & $\begin{array}{r}0.710586 \\
\pm 51\end{array}$ & 0.7065 & 9.54 & 51.69 & 0.1142 & $\begin{array}{r}0.512249 \\
\pm 8\end{array}$ & -4.35 & 1.27 \\
\hline $10 \mathrm{~A} .2$ & 119 & 662 & 0.522 & $\begin{array}{r}0.707788 \\
\pm 23\end{array}$ & 0.7055 & 7.92 & 44.54 & 0.1075 & $\begin{array}{r}0.512326 \\
\pm 10\end{array}$ & -2.58 & 1.14 \\
\hline $10 \mathrm{~A} .10$ & 210 & 245 & 2.487 & $\begin{array}{r}0.718255 \\
\pm 16\end{array}$ & 0.7074 & 7.34 & 39.11 & 0.1134 & $\begin{array}{r}0.512218 \\
\pm 10\end{array}$ & -4.92 & 1.32 \\
\hline 10A.14 & 151 & 540 & 0.811 & $\begin{array}{r}0.709214 \\
\pm 22\end{array}$ & 0.7057 & 7.27 & 42.66 & 0.1030 & $\begin{array}{r}0.512301 \\
\pm 8\end{array}$ & -2.89 & 1.16 \\
\hline 10A.16 & 248 & 138 & 5.208 & $\begin{array}{r}0.730860 \\
\pm 21\end{array}$ & 0.7080 & 30.20 & 6.44 & 0.1289 & $\begin{array}{r}0.512220 \\
\pm 14\end{array}$ & -5.50 & 1.36 \\
\hline 10A.17 & 215 & 614 & 1.016 & $\begin{array}{r}0.711143 \\
\pm 14\end{array}$ & 0.7067 & 8.49 & 51.02 & 0.1006 & $\begin{array}{r}0.512212 \\
\pm 11\end{array}$ & -4.54 & 1.29 \\
\hline 10A.19 & 104 & 723 & 0.417 & $\begin{array}{r}0.707127 \\
\pm 14\end{array}$ & 0.7053 & 7.54 & 45.58 & 0.1001 & $\begin{array}{r}0.512323 \\
\pm 7\end{array}$ & -2.35 & 1.12 \\
\hline $10 A .21$ & 157 & 701 & 0.647 & $\begin{array}{r}0.708934 \\
\pm 30\end{array}$ & 0.7061 & 58.26 & 10.31 & 0.1070 & $\begin{array}{r}0.512286 \\
\pm 24\end{array}$ & -3.34 & 1.20 \\
\hline 10A.29 & 260 & 184 & 4.094 & $\begin{array}{r}0.725622 \\
\pm 58\end{array}$ & 0.7077 & 46.54 & 8.25 & 0.1072 & $\begin{array}{r}0.512186 \\
\pm 13\end{array}$ & -5.30 & 1.35 \\
\hline $10 A .30$ & 75.2 & 396 & 0.549 & $\begin{array}{r}0.707305 \\
\pm 25\end{array}$ & 0.7049 & 25.59 & 5.43 & 0.1283 & $\begin{array}{r}0.512393 \\
\pm 7\end{array}$ & -2.09 & 1.10 \\
\hline
\end{tabular}

Analytical methods: Data obtained at the CRPG-CNRS (Nancy; France), using Rb-Sr and Sm-Nd separation techniques as reported in Michard et al, (1985) and Boher et al. (1992). Rb, Sr, Sm and Nd concentrations determined using the isotope dilution method, Sr and Nd isotopic ratios measured using a Cameca TSN 206 (for Rb and Sm concentrations) and a Finnigan MAT 262 mass spectrometers. Chemistry blanks are of about $0.8 \mathrm{ng}$ Sr for the acid dissolution and $2 \mathrm{ng} \mathrm{Nd}$ for the metaborate flux method. ${ }^{87} \mathrm{Sr} /{ }^{86} \mathrm{Sr}$ and ${ }^{143} \mathrm{Nd} /{ }^{144} \mathrm{Nd}$ ratios were normalized using ${ }^{86} \mathrm{Sr} /{ }^{88} \mathrm{Sr}=0.1194$ and ${ }^{146} \mathrm{Nd} /{ }^{144} \mathrm{Nd}=0.7219$, respectively. Analytical error on isotopic ratios are expressed as $2 \mathrm{~s}$.

$\left({ }^{87} \mathrm{Sr} /{ }^{86} \mathrm{Sr}\right)_{i}$ and $\varepsilon \mathrm{Nd}$ are calculated at the emplacement ages (syn-D3 granitoids: $317 \mathrm{Ma}$; late-D3 granitoids: $310 \mathrm{Ma}, 307 \mathrm{Ma}$ and $308 \mathrm{Ma}$ for Braga, Agrela and Celorico de Basto plutons, respectively), using ${ }^{143} \mathrm{Nd} /{ }^{144} \mathrm{Nd}=0.512638$ and ${ }^{147} \mathrm{Sm} /{ }^{144} \mathrm{Nd}=0.1967$ as CHUR parameters (Jacobsen and Wasserburg, 1984). $\mathrm{T}_{\mathrm{DM}}$ calculated according to the equation of Liew and Hofmann $(1988)$, using ${ }^{143} \mathrm{Nd} /{ }^{144} \mathrm{Nd}=0.513114$ and ${ }^{147} \mathrm{Sm} /{ }^{144} \mathrm{Nd}=0.222$ as DM parameters (Michard et al., 1985). Data on Braga pluton are from Dias and Leterrier (1994); * in spatial association with the Ucanha-Vilar granite.

\section{Sr-Nd isotopic data}

Syn-D3 biotite granitoids

These granitoids display a general negative correlation between ${ }^{87} \mathrm{Sr} /{ }^{86} \mathrm{Sr}$ initial ratios $\left(\mathrm{Sr}_{i}\right.$ ) and $\varepsilon N d$ values that vary in the range $0.7072-0.7106$ and -4.4 to -6.3 , respectively (Table 4 , Fig. 6A). The available data suggest
$\mathrm{Sr}$ and Nd isotopic homogenization within each granitic pluton. The Ucanha-Vilar and Refoios do Lima granites present the most extreme $\mathrm{Sr}_{i}$ and $\varepsilon N d$ values $\left(\mathrm{Sr}_{\mathrm{i}}=\right.$ $0.7072-0.7073, \varepsilon N d=-4.4$ to -4.8 and $\mathrm{Sr}_{\mathrm{i}}=0.7104$ $0.7106, \varepsilon \mathrm{Nd}=-6.0$ to -6.3 , respectively), while the other granites reveal an intermediate but similar isotopic composition $\left(\mathrm{Sr}_{\mathrm{i}}=0.7082-0.7085, \varepsilon \mathrm{Nd}=-4.6\right.$ to -5.4$)$. 
The isotopic signatures show progressive enrichment from South to North.

The granodioritic bodies associated with the UcanhaVilar granite reveal less-enriched $\mathrm{Sr}-\mathrm{Nd}$ isotopic compositions $\left(\mathrm{Sr}_{\mathrm{i}}=0.7064, \mathrm{\varepsilon Nd} \approx-3.3\right.$ ) when compared to the granite (Table 4, Fig. 6A).

\section{Late- $D 3$ biotite-dominant granitoids}

The late-D3 granites show different isotopic compositions relative to the syn-D3 group. The Braga and Agrela granites have similar isotopic compositions ( $\mathrm{Sr}_{\mathrm{i}}=$ 0.7064-0.7075, $\varepsilon N d=-5.0$ to -6.2 ) (Table 4, Fig. 6A) Within each granite unit the Sr-Nd data display small variations. The Gonça and Celorico de Basto granites show distinct compositions of more enriched isotopic signature $\left(\mathrm{Sr}_{\mathrm{i}}=0.7093, \varepsilon_{\mathrm{Nd}}=-6.8\right.$ and $\mathrm{Sr}_{\mathrm{i}}=0.7089-0.7090, \varepsilon_{\mathrm{Nd}}=$ -5.6 to -5.7 , respectively).
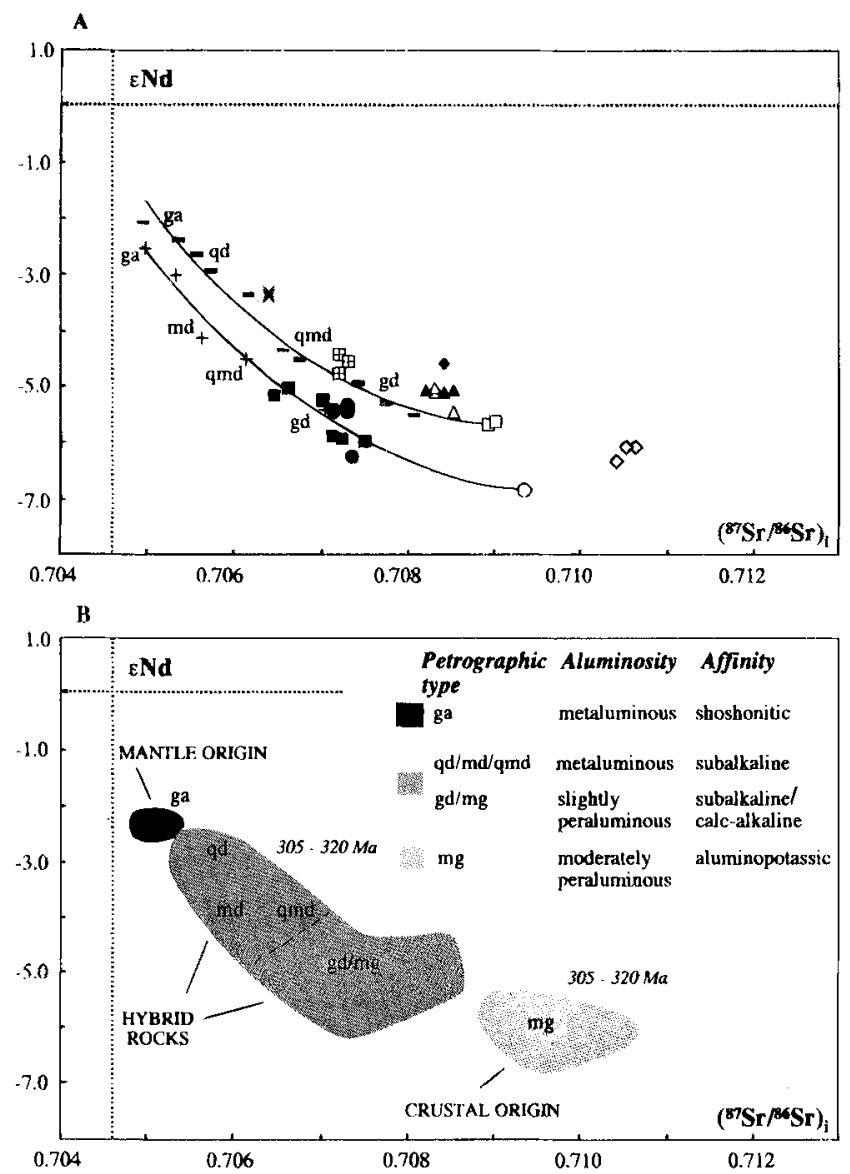

Fig. 6. $\varepsilon N d$ vs. $\mathrm{Sr}_{i}$ diagram for the studied syn- and late-D3 Hercynian granitic plutons (CIZ, northern Portugal). (A) Isotopic data plot and hyperbolic mixing curves for the Braga and Celorico de Basto series. (B) Relationship between isotope signatures, geochemical affinities and proposed genesis. ${ }^{87} \mathrm{Sr} /{ }^{86} \mathrm{Sr}$ initial ratios and $\varepsilon N d$ values calculated for the emplacement ages. Gabbro (ga), quartz-diorite (qd), monzodiorite (md), quartz. monzodiorite (qmd), granodiorite ( $\mathrm{gd}$ ), monzogranite $(\mathrm{mg})$. Legend as in figure 3.
Three gabbro-norite samples from the Braga and Celorico de Basto plutons reveal identical isotope composition $\left(\mathrm{Sr}_{\mathrm{i}}=0.7050, \mathrm{eNd}=-2.5\right.$ and $\mathrm{Sr}_{\mathrm{i}}=0.7049$ $0.7053, \varepsilon \mathrm{Nd}=-2.1$ to -2.4 , respectively) (Fig. 6). The isotope compositions of the other facies from the gabbrogranodioritic stocks are in the range 0.7053-0.7080 for $\mathrm{Sr}_{i}$ and -2.6 to -5.5 for $\varepsilon N d$, values intermediate between those obtained for the gabbro-norites and the corresponding host granites. In the $\varepsilon \mathrm{Nd} v \mathrm{vs} . \mathrm{Sr}_{i}$ diagram (Fig. 6A) the samples from these two plutons define distinct trends and are distributed close to hyperbolic mixing curves. These isotopic data do not support the hypothesis of a simple fractionation process relating all the members of each series.

From the integration of the isotopic data the following points can be emphasized (Fig. 6B):

(1) A clear relationship exists between isotope signatures and geochemical affinities for granites: (i) synand late-D3 moderately peraluminous granitoids of aluminopotassic affinity show the most enriched isotopic compositions ( $\mathrm{Sr}_{\mathrm{i}}=0.7089-0.7106$ and $\varepsilon_{\mathrm{Nd}}=-5.6$ to -6.8 ), (ii) syn- and late-D3 slightly peraluminous granitoids of calc-alkaline and subalkaline affinities display a more depleted isotopic signature $\left(\mathrm{Sr}_{\mathrm{i}}=0.7064\right.$ 0.7085 and $\varepsilon_{\mathrm{Nd}}=-4.4$ to -6.2 );

(2) The gabbros have similar isotopic compositions $\left(\mathrm{Sr}_{\mathrm{i}} \approx 0.705, \varepsilon_{\mathrm{Nd}} \approx-2\right)$;

(3) In the syn- and late-D3 groups, calc-alkaline and subalkaline series display continuous trends of increasing $\mathrm{Sr}_{\mathrm{i}}$ and decreasing $\varepsilon_{\mathrm{Nd}}$ from metaluminous (gabbros, quartzdiorites, monzodiorites, quartz monzodiorites) to peraluminous (granodiorites, monzogranites) rocks within the range $\mathrm{Sr}_{\mathrm{i}}=0.7049$ to 0.7106 and $\varepsilon_{\mathrm{Nd}}=-2.1$ to -6.8 .

\section{Granite Protoliths - A Discussion}

The geological, petrographic, mineralogical, chemical and isotopic data suggest that the studied plutons include three distinct genetic groups: mantle, crustal and hybrid rocks. From the integration of these data, potential magma sources can be discussed and characterized.

\section{Depleted versus enriched mantle}

The Braga and Celorico de Basto gabbronorites show chemical signature of shoshonitic rocks. Although having a primitive mantle-derived character $[(\mathrm{Mg} /(\mathrm{Fe}+\mathrm{Mg})=$ $0.68-0.72$ and $\mathrm{Cr}=439-626 \mathrm{ppm}]$, they do not reveal a depleted mantle signature $\left(\mathrm{Sr}_{\mathrm{i}}=0.7049-0.7053, \varepsilon_{\mathrm{Nd}}=\right.$ -2.1 to -2.5 ). It must be noted that the chemical and isotopic compositions of the gabbros are similar, revealing compositional homogeneity of the mantle component involved in the genesis of the Braga and Celorico de Basto plutons (Fig. 6B). 
$\mathrm{Sr}-\mathrm{Nd}$ isotope characteristics of the gabbros may be inherited from the protolith (enriched mantle) or result from a depleted mantle-derived magma affected by extensive assimilation or mixing with a geochemically more evolved crustal component. However an extensive crustal contamination would have induced high crystallization and fractionation of the basic magma, a process that is incompatible with the primitive chemical character of the studied gabbros. Therefore, we propose that they were probably derived from an enriched mantle which suggests the existence of a sub-Iberian enriched mantle domain during the Hercynian event. The enriched nature of sub-continental mantle domains within the Hercynian orogen is also referred in other sectors of the Iberian Massif (Moreno-Ventas et al., 1995; Galán et al., 1996), in the French Central Massif (Downes and Duthou, 1988; Pin and Duthou, 1990; Shaw et al., 1993) and in the Bohemian Massif (Gerdes et al., 1998; Janousek et al., 1995, 2000).

As proposed by Wenzel et al. (1997) and Janousek et al. (2000) for K-rich intrusions in the Bohemian Massif (Central European Hercynides), a subduction-related volatile influx may have been responsible for the enrichment in incompatible elements of the lithospheric mantle, whose later partial melting generated basic shoshonitic magmas with enriched isotopic compositions. A comparable origin can be envisaged for the studied gabbros.

\section{Crustal protoliths}

Some of the studied syn- and late-D3 granites show mineralogical and geochemical features that are characteristic of crustal-derived melts (Refoios do Lima, Gonça and Celorico de Basto granites). These are moderately peraluminous monzogranites $(A=25-52)$ with typical aluminopotassic affinity, in which the mafic microgranular enclaves are rare or absent. Low contents of $\mathrm{Al}$ - and Fe-rich biotites as well as Al-rich mineral phases (cordierite, andalusite, sillimanite) occur in these granites. As described above, the typological and geochemical characteristics of zircon populations from the Refoios do Lima granite, together with the presence of abundant relict cores, indicate a crustal origin for this granite (Simões, 2000). The three granites present the most evolved chemical compositions when compared to the other studied granites (lowest $\mathrm{Ba}, \mathrm{Sr}$ and REE whole-rock contents; more aluminous and less magnesian biotites), as well as a more enriched $\mathrm{Sr}-\mathrm{Nd}$ isotopic signature $\left(\mathrm{Sr}_{\mathrm{i}}\right.$ $=0.7089-0.7106, \mathrm{eNd}=-5.6$ to -6.8 , Fig. $6 \mathrm{~B}$ ). When comparing the Refoios do Lima, Gonça and Celorico de Basto granites, it must be noted that they reveal different mineralogical, chemical and isotopic compositions
(Figs. 3, 4 and 6A). Therefore an origin by partial melting of a compositionally heterogeneous continental crust is assumed, in which the contribution of a mantle-derived component is very small or even absent.

The composition of these monzogranites is different from that of melts produced experimentally from pelitic protoliths, rather suggesting a major involvement of metaigneous protoliths or metasedimentary sources derived from immature sediments (Conrad et al., 1988; Vielzeuf and Holloway, 1988; Holtz, 1989; Patiño Douce and Johnston, 1991; Johannes and Holtz, 1996 and references therein). Crustal protoliths with an appropriate $\mathrm{Sr}-\mathrm{Nd}$ isotopic composition were checked from the available isotopic data on the pre-Hercynian basement of the Iberian Massif. Felsic peraluminous granulites from the lower crust that occur as metaigneous xenoliths in the Spanish Central System (Iberian Massif; $\mathrm{Sr}_{305-320}=$ 0.706 to $0.713, \varepsilon_{\mathrm{Nd} 305-320}=-1$ to -8 ; Villaseca et al., 1999) are potential sources. The Nd isotopic compositions of felsic metaigneous rocks from the middle crust are similar to that of these monzogranites, but their $\mathrm{Sr}$ isotopic compositions are more radiogenic $\left(\mathrm{Sr}_{305-320}>0.715\right.$, $\varepsilon_{\mathrm{Nd} 305-320}=-4$ to -7 ; Beetsma, 1995; Villaseca et al., 1998). The high $\mathrm{Ba}$ and $\mathrm{Sr}$ contents as well as the high $\mathrm{K} / \mathrm{Rb}$ and $\mathrm{La}_{\mathrm{N}} / \mathrm{Yb}_{\mathrm{N}}$ ratios, mainly evident in the Refoios do Lima and Gonça monzogranites, imply a feldspar-rich protolith and a residue relatively poor in K-feldspar or biotite and rich in garnet. We therefore propose that the corresponding magmas were produced in the granulite facies by partial melting of felsic igneous or greywacke sources.

A similar Nd-depleted mantle model age of $1.4 \mathrm{Ga}$ was obtained for Refoios do Lima, Gonça and Celorico de Basto granites. $T_{D M}$ values in the range 1.2-1.6 Ga are usually found in peraluminous granites from the European Hercynides (Liew and Hofmann, 1988; Peucat et al., 1988; Pin and Duthou, 1990; Turpin et al., 1990; Beetsma, 1995; Janousek et al., 1995; Moreno-Ventas et al., 1995). These data could indicate the reworking of a continental crust generated in Mid-Proterozoic times. However there is no evidence of a major crust-forming event during this period in the Hercynian belt, thus the model ages rather indicate average crustal residence ages involving mixed crustal components of Archean and late Proterozoic sources (Peucat et al., 1988; Gebauer et al., 1989; Pin and Duthou, 1990).

Highly peraluminous leucogranites do not occur in the studied plutons. These leucogranites display highly evolved chemical and isotopic signatures $\left(\mathrm{Sr}_{i}>0.711\right.$, $\left.\varepsilon_{\mathrm{Nd}}<-7\right)$ and are largely represented in the CIZ, mainly as syn- to late-D3 magmatism, thus with synchronous emplacement relative to the less peraluminous biotite monzogranitic plutons (Dias et al., 1999). They are not 
genetically related. An origin by partial melting of upper crustal levels with a major contribution of aluminous metasedimentary sources is proposed for the highly peraluminous leucogranites (Dias et al., 1999).

Hybrid rocks

Hybridization processes between coeval crustal and mantle-derived magmas have been proposed to explain the field, petrographic, chemical and isotopic features of granodiorites and monzogranites in the European Hercynides and particularly in the Iberian Massif (Dias and Leterrier, 1994; Moreno-Ventas et al., 1995; Galán et al., 1996; Azevedo and Nolan, 1998; Castro et al., 1999; Menéndez and Ortega, 1999; Silva et al., 2000). In our study several evidences suggest interaction between coeval and contrasting magma types:

(1) The hybrid granites are associated with coeval basic to intermediate rocks and/or abundant mafic microgranular enclaves;

(2) Presence of net-veining structures and disequilibrium textures in the hybrid rocks (such as quartz 'ocelli' surrounded by a reaction rim of biotite or amphibole; irregular cores of plagioclase, surrounded by dendritic and more calcic rims; zircon crystals presenting resorption structures and $\mathrm{HfO}_{2}$ compositional discontinuity between two magmatic stages);

(3) Zircon populations from the hybrid syn-D granites show typological evolutionary trends that cross the domain of the calc-alkaline granites to the crustal granites, in contrast with what would be expected from a simple evolutionary crystallization process;

(4) For each series, the granites and associated mafic rocks define continuous and regular trends in major and trace element diagrams (Fig. 4) and are distributed close to hyperbolic mixing curves in the eNd vs. $\mathrm{Sr}_{i}$ diagram (Fig. 6A). In these diagrams the hybrid rocks plot between the gabbro-norites and the crustal monzogranites, displaying intermediate chemical and isotopic $\left(\mathrm{Sr}_{\mathrm{i}}=0.7053-0.7085\right.$ and $\varepsilon \mathrm{Nd}=-2.6$ to -6.2 ; Fig. $\left.6 \mathrm{~B}\right)$ compositions;

(5) Biotites from the Braga and Celorico de Basto series show curved evolutions which cross-cut the granitic typological fields from the subalkaline/calc-alkaline domains to the aluminopotassic one in the $\mathrm{Al}_{\text {total }}$ vs. $\mathrm{Mg}$ diagram of Nachit et al. (1985) (Fig. 3).

The above evidences argue against the following petrogenetic processes: (i) pure crustal origin for the slightly peraluminous biotite granodiorites/monzogranites, (ii) metasomatic transformation of solid basic material associated with granitic magma and (iii) simple fractional crystallization associating all the units in each granitoid series. The evidences rather suggest hybridization processes between coeval and contrasting liquids, which generated hybrid magmas, represented by the slightly peraluminous biotite granodiorites/ monzogranites (Ucanha-Vilar, Lamego, Felgueiras, Sameiro, Braga and Agrela granites) and by the associated dioritic-monzodioritic-granodioritic rock series. The felsic component is represented by the monzogranites of crustal origin (Refoios do Lima, Gonça and Celorico de Basto granites). The studied gabbros represent the basic component for the late-D3 composite plutons. Syn-D3 gabbroic rocks were not found at the present-day level of exposure, therefore the nature of the basic component for the syn-D3 plutons is not well constrained. However, the mixing line in the $\varepsilon N d$ vs. $\mathrm{Sr}_{i}$, $\mathrm{Sr}_{i}$ vs. $1 / \mathrm{Sr}$ and $\varepsilon \mathrm{Nd}$ vs. $1 / \mathrm{Nd}$ diagrams (Fig. $6 \mathrm{~A}$ and Simões, 2000) extrapolates to isotopic compositions similar to those of the late-D3 gabbroic rocks. It must be noted that the post-collisional stage of the Hercynian orogeny (syn- to post-D3, 300-320 Ma) was the main period of successive generation of granites without any significant geochronological gap (syn-D3, 313-320 Ma; late-D3, 306-311 Ma; late- to post-D3, ca. $300 \mathrm{Ma}$; Dias et al., 1998). Therefore, a basic component similar to the studied gabbros is not precluded for the genesis of the syn-D3 hybrid biotite granites.

The composite plutons show curved evolutions for some major and trace elements (Ti, Ba, Zr, La; Fig. 4), indicating that mineral fractionation was a main petrogenetic process. On the other hand, isotopic data are compatible with mixing processes between two contrasting magma types. Therefore, the chemical and $\mathrm{Sr}-\mathrm{Nd}$ isotopic compositions of the studied hybrid rocks can be explained by a complex petrogenetic process combining fractional crystallization and magma mixing between a mantlederived magma (represented by the gabbros) and felsic crustal magmas (represented by the Refoios do Lima, Gonça and Celorico de Basto granites). An AFC model (De Paolo, 1981) was applied to the Braga composite pluton (Dias and Leterrier, 1994) which suggests that fractional crystallization was the predominant process in the initial evolution of the basic magma, with increasing degree of contamination towards more acidic compositions. From this model the generation of the hybrid Braga granite would imply a high rate of fractional crystallization (72\%) and a moderate rate of crustal-melt contamination (34\%).

The three evolutionary trends in the $\varepsilon_{\mathrm{Nd}} \mathrm{vs}$. $\mathrm{Sr}_{\mathrm{i}}$ diagram (Fig. 6A) are ascribed to distinct crust-derived melts, generated from a heterogeneous source region in the lower crust, but the mantle-derived melt inputs had a similar enriched isotopic composition. Thus the differences in the isotopic composition of various hybrid rocks can be related to the heterogeneity of the crustal magmas and to the 
variable degree of crustal contribution. For the studied syn-D3 plutons the crustal contribution progressively decreases from north to south, in accordance with the progressive increase in the abundance of mafic microgranular enclaves. These features have led us to postulate the existence of independent reservoirs, in which distinct magma batches evolved independently by fractional crystallization and magma mixing processes.

\section{Hybrid granitoids and crustal growth}

Hybrid peraluminous granodiorites/monzogranites are largely represented in the CIZ of the Iberian Massif, being generated by complex petrogenetic processes combining fractional crystallization and hybridization between coeval mantle- and crust-derived magmas. Therefore, these processes played a significant role in the granitoid production during the Hercynian event, implying an important input of juvenile mantle magmas into the crust, as also emphasized by Castro et al. (1999). These authors describe melting-assimilation experiments carried out at $1000^{\circ} \mathrm{C}$ and 4,7 or $10 \mathrm{~kb}$ and using a proportion of $50 \%$ gabbro and $50 \%$ gneiss. These experiments account for such input and for the generation of high proportion $(>50$ vol.\%) silica-rich liquids whose compositions closely resemble those of the hybrid peraluminous granodiorites.

The abundance of hybrid syn- to late-D3 granitic rocks in the Iberian Massif, produced by mantle-crust interactions, indicates that a major episode of crustal growth took place during the late Paleozoic times of the Hercynian orogeny. This is in agreement with the proposal of Patiño Douce (1999) that "generation of granitic magmas is almost always associated in space and time with growth, rather than just recycling, of the continental crust".

In summary, the following conclusions can be stated:

(1) In the Hercynian Central Iberian Zone of the Iberian Massif large volumes of granitoids were emplaced during the last ductile deformation phase (D3, 300-320 Ma). This was the main period of successive granite generation, which exhibit composition variation, the biotite-dominant granitoids being the most abundant. They are frequently associated with gabbro-granodioritic stocks and mafic microgranular enclaves and show evidence of interaction between felsic and mafic magmas.

(2) In the syn- and late-D3 periods (320-305 Ma) moderately peraluminous monzogranites of aluminopotassic affinity were produced, which display the most enriched isotopic compositions. An essentially crustal origin by partial melting of a heterogeneous crust is proposed. Potential protoliths are metasedimentary (immature sediments) and/or felsic meta-igneous lower crustal material $\left(\mathrm{Sr}_{320-305}=0.709\right.$ to $0.711, \varepsilon_{\mathrm{Nd} 320-305}=-6$ to -7$)$.
(3) A large amount of hybrid magmas were generated by the interaction between these crust-derived liquids and a mantle-derived magma of shoshonitic affinity (equivalent to the gabbroic rocks) yielding an enriched isotopic signature. Slightly peraluminous monzogranites/ granodiorites of calc-alkaline and subalkaline affinities were produced by crystallization of these hybrid magmas. Chemical and $\mathrm{Sr}-\mathrm{Nd}$ isotopic data on the composite plutons (including basic to intermediate stocks) provide the evidence that the hybrid granitoids were generated by a complex petrogenetic process combining fractional crystallization and mixing between coeval mantle- and crustal-derived magmas (at variable degrees) in independent magma reservoirs.

(4) Mantle-derived melt inputs have a similar enriched isotopic composition, but crustal magmas are heterogeneous in composition. Thus the differences in the isotopic composition of various hybrid rocks are related to the heterogeneity of the crustal source region in lower crust and also to variable degrees of crustal contamination.

(5) In the Iberian Massif an extensive crustal recycling event occurred at the post-collisional stage of the Hercynian orogeny. The abundance of hybrid granitoids, implying a significant input of juvenile mantle magma, indicates the occurrence of an important crustal growth episode together with the recycling processes.

\section{Acknowledgments}

This research was carried out at the Centro de Ciências do Ambiente - Ciências da Terra (University of Minho, Portugal), a R and D Unit from FCT (Fundação para a Ciência e a Tecnologia, Portugal). The authors wish to thank the CRPG (CNRS, France) for analytical support and A. Simões Francisco for field assistance. Two anonymous referees and the editors are also thanked for their comments and useful suggestions. Financial support was provided by FCT (project PRAXIS 2/2.1/391/94), France-Portugal Scientific Cooperation Programs and by the University of Minho.

\section{References}

Allègre, C.J. and Ben Othman, D. (1980) Nd-Sr isotopic relationship in granitoid rocks and continental crust development: a chemical approach to orogenesis. Nature, v. 286, pp. 335-341.

Azevedo, M.R. and Nolan, J. (1998) Hercynian late-post-tectonic granitic rocks from the Fornos de Algodres area (northern Central Portugal). Lithos, v. 44, pp. 1-20.

Bea, F., Montero, P. and Molina, J.F. (1999) Mafic precursors, peraluminous granitoids, and late lamprophyres in the Avila batholith: a model for the generation of Variscan batholiths in Iberia. J. Geol., v. 107, pp. 399-419. 
Beetsma, J.J. (1995) The late Proterozoic/Paleozoic and Hercynian crustal evolution of the Iberian Massif, N Portugal. Ph.D. Thesis, Vrije Universiteit Amsterdam. 223p.

Boher, M., Abouchami, W., Michard, A., Albarède, F. and Arndt, N.T. (1992) Crustal growth in West Africa at $2.1 \mathrm{Ga}$. J. Geophys. Res., v. 97, pp. 345-369.

Castro, A., Patiño Douce, A.E., Corretgé, L.G., De La Rosa, J.D., El-Biad, M. and El-Hmidi, H. (1999) Origin of peraluminous granites and granodiorites, Iberian massif, Spain: an experimental test of granite petrogenesis. Contrib. Mineral. Petrol., v. 135, pp. 255-276.

Cocherie, A., Rossi, Ph., Fouillac, A.M. and Vidal, Ph. (1994) Crust and mantle contributions to granite genesis - an example from the Variscan batholith of Corsica, France, studied by trace-element and $\mathrm{Nd}-\mathrm{Sr}-\mathrm{O}$-isotope systematics. Chem. Geol., v. 115, pp. 173-211.

Collins, W.J. (1996) Lachlan Fold Belt granitoids: products of three component mixing. Trans. R. Soc. Edinburgh Earth Sci., v. 87, pp. 171-181.

Conrad, W.K., Nicholls, I.A. and Wall, V.J. (1988) Water-saturated and undersaturated melting of metaluminous and peraluminous crustal composition at $10 \mathrm{~kb}$ : evidence for the origin of silicic magmas in the Taupo Volcanic Zone, New Zealand, and other occurrences. J. Petrol., v. 29, pp. 765-803.

De Paolo, D.J. (1981) Trace element and isotopic effects of combined wallrock assimilation and fractional crystallisation. Earth Planet. Sci. Lett., v. 53, pp. 189-202.

Dias, G. and Leterrier, J. (1993) Cronologia e petrogénese de granitóides biotíticos tardi-hercínicos (Minho, Portugal). Estudo isotópico Rb-Sr e Sm-Nd. Publ. Mus. Lab. Min. Geol. Univ. Porto, v. 3, pp. 369-373.

Dias, G. and Leterrier, J. (1994) The genesis of felsic-mafic plutonic associations: a $\mathrm{Sr}$ and $\mathrm{Nd}$ isotopic study of the Hercynian Braga granitoid massif (northern Portugal). Lithos, v. 32, pp. 207-223.

Dias, G., Leterrier, J., Ferreira, N. and Lopes Nunes, J.E. (1992) Les granitö̈des biotitiques syn-à tardi-hercyniens de la région de Braga (Nord Portugal). Typologie chimico-minéralogique et implications pétrogénétiques. C.R. Acad. Sci. Paris, 314, série II, pp. 675-681.

Dias, G., Leterrier, J., Mendes, A., Simões, P.P. and Bertrand, J.M. (1998) U-Pb zircon and monazite geochronology of post-collisional Hercynian granitoids from the Central Iberian Zone (northern Portugal). Lithos, v. 45, pp. 349-369.

Dias, G., Simões, P.P., Mendes, A. and Leterrier, J. (1999) Sr-Nd isotopic constraints on the genesis of Hercynian granitoids from the Central Iberian Zone, northern Portugal. In: Barbarin, B. (Ed.), The origin of granites and related rocks. $4^{\text {th }}$ Hutton Symp., Abstract vol., Doc. BRGM, Orléans, 290, p. 208.

Didier, J, and Barbarin, B. (Eds.), (1991) Enclaves and granite petrology. Developments in petrology 13, Elsevier, Amsterdam, 625p.

D'Lemos, R.S. (1996) Mixing between granitic and dioritic crystal mushes, Guernsey, Channel Islands, UK. Lithos, v. 38 , pp. $233-257$.

Downes, H. and Duthou, J.L. (1988) Isotopic and trace element arguments for the lower-crustal origin of Hercynian granitoids and pre-Hercynian orthogneisses, Massif Central (France). Chem. Geol., v. 68, pp. 291-308.
Evensen, N.M., Hamilton, P.J. and O'Nions, R.K. (1978) Rareearth abundances in chondritic meteorites. Geochim. Cosmochim. Acta, v. 42, pp. 1199-1212.

Ferreira, N., Iglesias, M., Noronha, F, Pereira, E., Ribeiro, A. and Ribeiro, M.L. (1987a) Granitóides da Zona Centro Ibérica e seu enquadramento geodinâmico. In: Bea, F., Carnicero, A., Gonzalo, J.C., López Plaza, M. and Rodriguez Alonso, M.D. (Eds.), Geologia de los granitoides y rocas asociadas del Macizo Hespérico. Ed. Rueda, Madrid, pp. 37-51.

Ferreira, N., Macedo, C.A.R. and Sousa, M.B. (1987b) Cronostratigrafia dos granitos da região de Moimenta da Beira-Tabuaço-Penedono. Publ. Mus. Lab. Min. Geol, Univ. Porto, 1, pp. 287-302.

Galán, G., Pin, C. and Duthou, J.-L. (1996) Sr-Nd isotopic record of multi-stage interactions between mantle-derived magmas and crustal components in a collision context - the ultramafic-granitoid association from Vivero (Hercynian belt, NW Spain). Chem. Geol., v. 131, pp. 67-91.

Gebauer, D., Williams, I.S., Compston, W. and Grünenfelder, M. (1989) The development of the Central European continental crust since the early Archaean based on conventional and ion-microprobe dating of up to 3.84 by old detrital zircons. Tectonophys., v. 157, pp. 91-96.

Gerdes, A., Wörner, G. and Friedrich, F. (1998) Late-orogenic magmatism in the southern Bohemian Massif - geochemical and isotopic constraints on possible sources and magma evolution. Acta Univ. Carolinae - Geologica, v. 42, pp. 41-45.

Helal, B. (1992) Granitoïdes, granites à métaux rares et hydrothermalisme associé: géologie, minéralogie et géochimie de plusieurs suites tardi-hercyniennes (Nord du Portugal). Ph.D. Thesis (Unpub.), École Nationale Supérieure des Mines de Saint-Étienne, Saint-Étienne, France, $507 \mathrm{p}$.

Holden, P., Halliday, A.N. and Stephens, W.E. (1987) Neodymium and strontium isotope content of microdiorite enclaves points to mantle input into granitoid production. Nature, v. 330 , pp. 53-55.

Holtz, F. (1989) Importance of melt fraction and source rock composition in crustal genesis - the example of two granitic suites of northern Portugal. Lithos, v. 24, pp. 21-35.

Jacobsen, S.B. and Wasserburg, G.J. (1984) Sm-Nd isotopic evolution of chondrites. Earth Planet. Sci. Lett., v. 50, pp. 139-155.

Janousek, V., Rogers, G. and Bowes, D.R. (1995) Sr-Nd isotopic constraints on the petrogenesis of the Central Bohemian Pluton, Czech Republic. Geol. Rundsch., v. 84, pp. 520-534.

Janousek, V., Bowes, D.R., Rogers, G., Farrow, C.M. and Jelínek, E. (2000) Modelling diverse processes in the petrogenesis of a composite batholith: the Central Bohemian pluton, Central European Hercynides. J. Petrol., v. 41, pp. 511-543.

Jayananda, M., Martin, H., Peucat, J.J. and Mahabaleswar, B. (1995) Late Archaean crust-mantle interactions: geochemistry of LREE-enriched mantle derived magmas. Example of the Closepet batholith, southern India. Contrib. Mineral. Petrol., v. 119, pp. 314-329.

Johannes, W. and Holtz, F. (1996) Petrogenesis and experimental petrology of granitic rocks. Springer-Verlag, Berlin, $335 p$. 
La Roche, H., Leterrier, J., GrandClaude, P. and Marchal, M. (1980) A classification of volcanic and plutonic rocks using R1-R2 diagram and major element analyses - its relationships with current nomenclature. Chem. Geol., v. 29, pp. 183-210.

Leake, B.E., Woolley, A.R., Arps, C.E.S., Birch, W.D., Gilbert, M.C., Grice, J.D., Hawthorne, F.C., Kato, A., Kisch, H.J., Krivovichev, V.G., Linthout, K., Laird, J., Mandarino, J., Maresch, W.V., Nickel, E.H., Rock, N.M.S., Schumacher, J.C., Smith, D.C., Stephenson, N.C.N., Ungaretti, L., Whittaker, E.J.W. and Youzhi, G. (1997) Nomenclature of amphiboles: report of the subcommittee on amphiboles of the International Mineralogical Association Commission on new minerals and mineral names. Mineral. Mag., v. 61, pp. 295-321.

Liew, T.C. and Hofmann, A.W. (1988) Precambrian crustal components, plutonic associations, plate environment of the Hercynian Fold Belt of central Europe: indications from a $\mathrm{Nd}$ and Sr isotopic study. Contrib. Mineral. Petrol., v. 98, pp. 129-138.

Macera, P., Del Moro, A., Bargossi, G.M., Campana, R. and Rottura, A. (1994) Polygenetic nature of the Cima d'Asta intrusive complex, southern Alps, Italy. Inferences from petrological, geochemical and isotopic ( $\mathrm{Sr}$ and $\mathrm{Nd}$ ) data. Lithos, v. 32, pp. 47-62.

Martins, H.C.B., Almeida, A., Noronha, F. and Leterrier, J. (1999) $\mathrm{U}-\mathrm{Pb}$ zircon and monazite geochronology of Hercynian composite granite plutons, northern Portugal. In: Barbarin, B. (Ed.), The origin of granites and related rocks. $4^{\text {th }}$ Hutton Symp., Abstract vol., Doc. BRGM, Orléans, 290, p. 215.

Martins, M.E.R. (1997) Geologia, petrologia e geoquímica dos granitóides hercínicos da região de Lamego (Norte de Portugal). Ph.D. Thesis (Unpub.), Universidade de Aveiro, Aveiro, Portugal, 287p.

Menéndez, M. and Ortega, L.A. (1999) Evidence of magmatic hybridization related with feeding zones: the synkinematic Guitiriz granitoid, NW Iberian massif. In: Castro, A., Fernández, C. and Vigneresse, J.L. (Eds.), Understanding granites: integrating new and classical techniques. Geological Society, London, Spl. Publ., v. 168, pp. 255272 .

Michard, A., Gurriet, P., Soudant, M. and Albarède, F. (1985) Nd isotopes in French Phanerozoic shales: external vs.internal aspects of crustal evolution. Geochim. Cosmochim. Acta, v. 49, pp. 601-610.

Moreno-Ventas, I., Rogers, G. and Castro, A. (1995) The role of hybridization in the genesis of Hercynian granitoids in the Gredos massif, Spain: inferences from $\mathrm{Sr}-\mathrm{Nd}$ isotopes. Contrib. Mineral. Petrol., v. 120, pp. 137-149.

Nachit, H., Razafimahefa, N., Stussi, J.M. and Carron, J.P. (1985) Composition chimique des biotites et typologie magmatique des granitoïdes. C.R. Acad. Sci. Paris, v. 301, pp. 813-818.

Pagel, M. and Leterrier, J. (1980) The subalkaline potassic magmatism of the Ballons massif (southern Vosges, France): shoshonitic affinity. Lithos, v. 13, pp. 1-10.

Pankhurst, R.J., Hole, M.J. and Brook, M. (1988) Isotope evidence for the origin of Andean granites. Trans. R. Soc. Edinburgh, Earth Sci., v. 79, pp. 123-133.

Patiño Douce, A.E. (1999) What do experiments tell us about the relative contributions of crust and mantle to the origin of granitic magmas? In: Castro, A., Fernández, C. and
Vigneresse, J.L. (Eds.), Understanding granites: integrating new and classical techniques. Geol. Soc., London, Spl. Publ, v. 168 , pp. $55-75$.

Patiño Douce, A.E. and Johnston, A.D. (1991) Phase equilibria and melt productivity in the pelitic system: implications for the origin of peraluminous granitoids and aluminous granulites. Contrib. Mineral. Petrol., v. 107, pp. 202-218.

Pearce, J.A. (1982) Trace element characteristics of lavas from destructive plate boundaries. In: Thorpe, R.S. (Ed.), Andesites. Wiley, Chichester, pp. 525-548.

Pereira, E. (1987) Estudo geológico-estrutural da região de Celorico de Basto e sua interpretação geodinâmica. Ph.D. Thesis (Unpub.), Serviços Geológicos de Portugal, Lisboa, 274p.

Peucat, J.J., Jegouzo, P., Vidal, P. and Bernard-Griffiths, J. (1988) Continental crust formation seen through the $\mathrm{Sr}$ and $\mathrm{Nd}$ isotope systematics of S-type granites in the Hercynian belt of western France. Earth Planet. Sci, Lett., v. 88, pp. 60-68.

Pin, C. and Duthou, J.-L. (1990) Sources of Hercynian granitoids from the French massif Central: inferences from Nd isotopes and consequences for crustal evolution. Chem. Geol., v. 83, pp. 281-296.

Pupin, J.P. (1980) Zircon and granite petrology. Contrib. Mineral. Petrol., v. 73, pp. 207-220.

Pupin, J.P. (1988) Granites as indicators in paleogeodynamics. Rend. Soc. Ital. Mineral. Petrol., v. 43, pp. 237-262.

Pupin, J.P. (1992) Les zircons des granites océaniques et continentaux: couplage typologie-géochimie des éléments en traces. Soc. Géol. France, Bull., v. 163, pp. 495-507.

Pupin, J.P. (1994) Caractérization des protolithes des migmatites et granites anatectiques crustaux d'après l'étude des zircons. C.R. Acad. Sci. Paris, 319, série II, pp. 1191-1197.

Shaw, A., Downes, H. and Thirlwall, M.F. (1993) The quartzdiorites of Limousin: elemental and isotopic evidence for Devono-Carboniferous subduction in the Hercynian belt of the French massif Central. Chem. Geol., v. 107, pp. 1-18.

Silva, M.M.V.G., Neiva, A.M.R. and Whitehouse, M.J. (2000) Geochemistry of enclaves and host granites from the Nelas area, Central Portugal. Lithos, v. 50, pp. 153-170.

Simões, P.P. (2000) Instalação, geocronologia e petrogénese de granitóides biotíticos sintectónicos associados ao cisalhamento Vigo-Régua (ZCI, Norte de Portugal). Ph.D. Thesis (Unpub.), Universidade do Minho, Braga, Portugal, $351 \mathrm{p}$.

Turpin, L., Cuney, M., Friedrich, M., Bouchez, J.L. and Aubertin, M. (1990) Meta-igneous origin of Hercynian peraluminous granites in NW French massif Central: implications for crustal history reconstructions. Contrib. Mineral. Petrol., v. 104, pp. 163-172.

Veloso, M.L. (1994) Estudo petrográfico e químico-mineralógico de encraves microgranulares máficos associados a granitos biotíticos tardi-hercínicos da região de Braga-Vieira do Minho (Norte de Portugal). Master Thesis (Unpub.), Universidade do Minho, Braga, Portugal, 181p.

Veloso, M.L. and Dias, G. (1995) Estudo químico-mineralógico de encraves microgranulares máficos associados a granitóides tardi-hercínicos da região de Braga-Vieira do Minho (Norte de Portugal): tipo e mecanismos de hibridação. Memórias, Publ. Mus. Lab. Min. Geol. Univ. Porto, 4, pp. 843-847.

Vielzeuf, D. and Holloway, J.R. (1988) Experimental 
determination of the fluid-absent melting relations in the pelitic system. Contrib. Mineral. Petrol., v. 98, pp. 257-276.

Villaseca, C., Barbero, L. and Rogers, G. (1998) Crustal origin of Hercynian peraluminous granitic batholiths of Central Spain: petrological, geochemical and isotopic ( $\mathrm{Sr}, \mathrm{Nd}$ ) constraints. Lithos, v. 43, pp. 55-79.

Villaseca, C., Downes, H., Pin, C. and Barbero, L. (1999) Nature and composition of the lower continental crust in Central
Spain and the granulite-granite linkage: inferences from granulitic xenoliths. J. Petrol., v. 40, pp. 1465-1496.

Wenzel, T., Mertz, D.F, Oberhänsli, R. and Becker, T. (1997) Age, geodynamic setting and mantle enrichment processes of a K-rich intrusion from the Meissen massif (northern Bohemian massif) and implications for related occurrences from the mid-European Hercynian. Geol. Rundsch., v. 86, pp. 556-570. 